\title{
CEO Age, Risk Incentives and Hedging Instrument Choice
}

\author{
Ettore Croci ${ }^{\mathrm{a}}$, Håkan Jankensgård ${ }^{\mathrm{b}}$
}

\section{This version: May 8, 2014}

\begin{abstract}
We analyze how firms hedge in the oil and gas industry. Our main finding is that CEO age determines hedging behavior. The probability of being a hedger as well as the use of linear hedging strategies decreases with CEO age. These results are consistent with an argument that financial distress, which sends a negative signal of managerial ability, is relatively more costly to younger CEOs. We also investigate the vega-theory of hedging instrument choice, finding some support for a negative relationship between vega and a) the use of derivatives and b) hedging strategies that include the sale of call options.
\end{abstract}

Key words: Vega, executive compensation, hedging, options, CEO age.

JEL code: G30, G32

${ }^{a}$ Department of Economics and Business Administration, Università Cattolica del Sacro Cuore, Milan, Italy. Email: ettore.croci@unicatt.it

${ }^{\mathrm{b}}$ Corresponding author. Department of Business Administration and Knut Wicksell Centre for Financial Studies, Lund University, Sweden. Email: Hakan.Jankensgard@fek.lu.se

The authors wish to thank Tom Aabo, Gustav Martinsson, Martin Strieborny, Jens Forssbaeck, Ramin Baghai, Frederik Lundtofte, Daniel Metzger, seminar participants at Stockholm School of Economics, and seminar participants at Knut Wicksell Centre for Financial Studies, Lund University. Jankensgård gratefully acknowledges the financial support of the Jan Wallander and Tom Hedelius foundation and the Tore Browaldh foundation. 


\section{Introduction}

The use of financial derivatives to manage a firm's risk profile is widespread (Bodnar, Hayt and Marston, 1998; Adam, 2009). In spite of this, the question of how firms hedge, i.e. its choice of linear and non-linear financial instruments, has typically received much less attention in the academic literature than the corresponding question of why firms hedge. A notable exception is Adam (2009) who investigates the use of option-based hedging strategies in the gold mining industry. The results in Adam's paper show that the use of options is systematically related to a firm's financial status, consistent with the predictions of the model in Adam (2002).

In this paper we extend this line of inquiry by analyzing if managerial risk preferences impact how firms choose between linear and non-linear hedging instruments. We capture managerial risk preferences through CEO age and the risk-taking incentives provided by the CEO's compensation contract. Previous research has shown that CEO age is related to corporate policies and risk-taking (Yim, 2013; Serfling, 2014). CEOs face varying degrees of career risk depending on age (Scharfstein and Stein, 1990; Hirschleifer and Thakor, 1992; Holmstrom, 1999), and physiological as well as psychological changes that occur with age could influence on the willingness to take risk (Hambrick and Mason, 1984; Bertrand and Mullainathan, 2003). The power of compensation-based risk-taking incentives to explain corporate risk-taking has also attracted considerable attention in the academic literature (Tufano, 1996; Knopf et al, 2002; Rajgopal and Shevlin, 2002; Coles et al, 2006; Hayes et al, 2012).

We first develop a hypothesis of age-related CEO hedging preferences based on an assessment of career risk. Hedging exposures to risk is typically considered to reduce the variability of the firm's payoff distribution and thereby reduce financial distress risk (e.g. Smith and Stulz, 1985). Assuming that financial distress creates a signal of low ability, younger CEOs would prefer to hedge more 
because they suffer the consequences of an impaired reputation over a longer career-horizon. This conjecture is similar in spirit to the argument in Yim (2013) that younger CEOs can reap the benefits of the pay-increase that typically accompany acquisitions over a longer time-horizon. We also consider a competing hypothesis regarding the impact of CEO age on hedging behavior. According to the 'quiet life'-hypothesis, older CEOs are more averse to financial distress-risk due to the physical and mental strain such a situation entails (see Bertrand and Mullainathan, 2003, and Yim, 2013, for arguments on the preference of older CEOs for the quiet life). In addition, financial distress may involve cutbacks that adversely affect an organization to which old CEOs tend to have greater psychological commitment than younger ones (Stevens, Beyer, and Trice, 1978). The career risk- and quiet life-hypotheses have implications in terms of hedging instrument choice. Linear hedging instruments (e.g. forwards) have the highest 'hedging intensity' since they lock in the forward rate, as opposed to option-based hedging contracts, which typically have strike prices different from the forward rate and, thus, are less likely to alter the payoff distribution. Given that they are more effective in reducing variability linear contracts would be preferred by younger CEOs according to the career-risk hypothesis, whereas the quiet-life hypothesis predicts that older CEOs would prefer the linear strategy.

To generate empirical predictions with regard to compensation-based risk incentives, we apply the insights of Smith and Stulz (1985) to the choice of linear vs. non-linear hedging strategies. Smith and Stulz (1985), who analyze how the propensity of managers to hedge can be influenced by the convexity of the compensation contract, show that a more pronounced convexity with respect to firm value (henceforth "vega"1) induces a risk-seeking behavior that counteracts managers' natural risk aversion. According to the vega-theory of hedging instrument choice, managers with a convex compensation schedule would be less willing to employ hedging strategies that sacrifice upside

\footnotetext{
${ }^{1}$ Vega is typically defined as the dollar sensitivity of managerial wealth to a small change in the volatility of the underlying asset (see Guay, 1999).
} 
potential, i.e. linear contracts and/or the selling of call options, because they reduce the potential windfalls from price increases in the hedgeable risk factor. According to this hypothesis, managers should display a "pecking order" of hedging preferences, in which hedging strategies are less preferred the more upside they give away. ${ }^{2}$

We empirically test how managerial risk incentives impact hedging instrument choice using a sample of US oil and gas firms included in the S\&P 1500 between 2000 and 2008. This industry is suitable for our purposes because it is comparatively homogenous, yet offers substantial variation in hedge ratios (Jin and Jorion, 2006). Also, this industry is one of very few in which sufficient data on derivative positions is available to make a study on hedging instrument choice. Thanks to the extensive disclosure of oil and gas firms in this regard we are able to hand-collect detailed data from 10-Ks, allowing us to distinguish between the different hedging strategies. Moreover, the sample period spans two market regimes: the 2000 to 2004 period, characterized by a "stable" oil price, and the 2005 to 2008 period, characterized by a sharply rising oil price that successively reached new record levels. This feature allows us to examine the determinants of hedging behavior under two different sets of market conditions.

Our main finding is that CEO age is strongly related to firms' derivative usage. CEO age is negatively related to the probability of using derivatives, as well as to the probability of employing linear hedging strategies. In our empirical model we use a rich set of governance and financial control variables that theory suggests are related to the hedging decision. Following Yim (2013) we control for the possibility that CEO age reflects the causal effect of other CEO characteristics, like financial expertise and overconfidence, which may be correlated with age. For example, CEOs who

\footnotetext{
${ }^{2}$ A similar pecking order, but with the opposite sign, is predicted by delta, i.e. the dollar sensitivity of managerial wealth to a small change in the value of the underlying stock price. Also note that the way our argument is phrased assumes that the firm has a long position in the underlying risk factor, i.e. that it hedges its output price, though the same logic obviously applies to firms that hedge their input price.
} 
are financial experts, either because they previously held finance-related jobs or because they have a finance-related degree, may be more inclined to use financial hedging. The findings with regard to CEO age are also robust to different model specifications. In particular, CEO age is negatively associated to the ratio of linear hedging instruments to the firm's total derivative portfolio, and to the ratio of linear hedging scaled by production. Overall, these findings provide support for the career risk-hypothesis, but contradict the quiet life-hypothesis.

We consider alternatives to the causality interpretation of the age effect. The association may simply reflect an endogenous relation. In particular, risk-averse boards could hire younger CEOs because they desire more active derivative usage. As argued by Yim (2013), such a board-induced impact on corporate policy (in our case hedging behavior) should be most pronounced in the years following a new hiring. We show that the age effect is robust to including only long-tenured CEOs. Moreover, following Serfling (2014), we instrument CEO age with CPI at birth and show that the age effect is even stronger.

The predictions of the vega-theory find mixed empirical support. Consistent with the predictions of the theory, vega is negatively related to the probability of using derivatives, and of using strategies that involve the selling of call options. Selling call options implies capping the upside potential with respect to the oil price, which high-vega managers have a larger incentive to preserve. However, when we restrict our analysis to hedgers, we find results that do not support the vega-theory of hedging. In fact, conditional on the decision to hedge, vega is positively related to using a linear strategy. ${ }^{3}$ This finding is inconsistent with the vega-theory since a linear hedge gives up comparatively more upside than a collar.

\footnotetext{
${ }^{3}$ This conditional test is essentially a comparison of the propensity to use one of the two dominating hedging strategies in the oil and gas industry: a linear hedge or a collar strategy. A collar strategy involves the simultaneous purchase of a put option and the selling of a call option.
} 
This paper offers several contributions to the literature. Adam (2009) analyzes how financial status affects hedging instrument choice but does not control for managerial risk incentives, which previous literature on corporate hedging has identified as an important influence on hedging decisions (e.g. Tufano, 1996). Our paper fills this gap. Adam (2009) finds that financially constrained firms are more likely to sell call options to finance the purchase of put options (or to finance investments in real assets). Financially unconstrained firms, on the other hand, are more likely to purchase put options financed with cash-on-hand. We find no convincing evidence in support of the theory that hedging instrument choice is driven by financial constraints. However, when interpreting this result we should keep in mind the differences in the samples analyzed. Whereas Adam's sample consists of gold mining firms, which tend to be small and operate with modest profit margins, our sample is made up of large oil and gas firms included in the S\&P 1500 .

Our paper also contributes to the literature on how CEO characteristics influence corporate risktaking. In a recent paper, Serfling (2014) documents that younger CEOs take more risk. Specifically, firms with younger CEOs invest more in R\&D; make less diversifying acquisitions; and have more operating leverage. Yim (2013) finds that younger CEOs are more prone to make acquisitions. These findings seem to confirm the general portrayal of younger CEOs as more riskseeking in the management and psychology literatures (see Yim, 2013, for a discussion of this literature). While at first glance the results in our paper appear to disagree with these findings, a reconciliation is possible if we consider the type of risk-taking being analyzed and differences in the incentives related to each. Whereas younger managers have stronger incentives to make an acquisition early on in their career to reap the benefits from the associated pay-increase, the incentives to take substantial price risk are the opposite. If a firm experiences financial distress due to price risk, this may serve as a negative signal of managerial ability, which is relatively more costly to a younger CEO with more active years remaining and without accumulated wealth. Another way these findings could be reconciled is by considering that it is potentially erroneous to 
consider the relation between $\mathrm{CEO}$ age and financial hedging in isolation. One possible interpretation is that younger CEOs hedge the firm's financial risk to a greater extent because they are more aggressive risk-takers in other areas. On this reading, more extensive financial hedging balances and supports the younger CEOs more aggressive risk-taking in real assets. To investigate this proposition we carry out regressions with proxies for risk-taking in real assets as dependent variables (exploration expenses, capital expenditure, and acquisition spending). We do not find any convincing evidence in support of the complementarity-argument. However, we believe the complementarity between financial and real risk-taking at the CEO level offers an interesting venue for future research on corporate risk-taking.

Finally, our findings also contribute to a growing body of research that investigates if managerial risk-taking incentives influence corporate risk-taking. Several papers have found an association between vega and various proxies for risk-taking, such as R\&D, leverage, and cash holdings (Rajgopal and Shevlin, 2002; Coles et al, 2006; Hayes et al, 2012), though other papers do not find clear support for such a relation (e.g. Lewellen, 2006; Hayes et al. 2012). A few papers have investigated this issue using corporate hedging as proxy for risk-taking (Tufano, 1996; Haushalter, 2000; Knopft et al., 2002; Rogers, 2002). The evidence is best described as mixed. ${ }^{4}$ None of these papers, however, look specifically at the hedging instrument choice. The evidence in this paper provides some support for the notion that vega is negatively associated with the use of derivatives, as predicted by the theory. In terms of the choice of hedging strategy we document a negative association between vega and the selling of call options to finance put options.

\footnotetext{
${ }^{4}$ Tufano (1996) finds that the number of options held by managers, a somewhat crude approximation of vega, is negatively correlated with the use of hedging. Haushalter (2000) investigates similar proxies for vega in the oil and gas industry and finds conflicting results. Knopf et al (2002), using a broad sample of firms, find no significant relation between vega and hedging. Rogers (2002), using simultaneous equation modeling, does find the expected negative relationship between vega and hedging.
} 
The paper proceeds as follows. Section 2 reviews previous literature and outlines the hypotheses related to hedging instrument choice. Section 3 introduces the sample and variables, and also provides descriptive statistics. Section 4 presents the results from the empirical analysis of hedging instrument choice. Section 5 continues this analysis by examining alternatives to the causality interpretation of our results. Section 6 concludes the paper.

\section{Theories of hedging instrument choice}

\subsection{Theories based on CEO characteristics}

Several theories exist relating CEO characteristics to corporate policies. One characteristic that has attracted significant attention in the literature is CEO age (see Yim, 2013, Serfling, 2014). Age may be systematically related to risk preferences both due to changing incentives over the CEO's career and due to changing CEO characteristics, both physiological and psychological, as the CEO gets older.

Concerns about career risk can generate potential differences in risk preferences among younger and older CEOs. In the model by Prendergast and Stole (1996) managers take greater risks to signal ability. Serfling (2014) cites anecdotal evidence that portray younger CEOs as more risk-seeking. However, evidence from mutual fund managers and security analysts suggests younger managers display risk-averse behavior because they face greater risk of being fired following poor performance (Chevalier and Ellison, 1999; Hong, Kubik, and Solomon, 2000). In the context of hedging, career concerns would suggest that younger CEOs have stronger incentives to engage in financial hedging. To see this, consider that financial distress generates a negative signal of managerial ability. This would be relatively more costly for younger CEOs, because the negative impact on reputation would apply over a longer career-horizon. Also, if older CEOs are wealthier, they have a stronger financial buffer and presumably more possibilities for holding a diversified 
portfolio of financial assets. Besides predicting more hedging, these arguments also generate a prediction in terms of hedging instrument choice: since linear hedging instruments are the most 'hedging intense' these would be preferred by risk-averse managers. ${ }^{5}$

Bertrand and Mullainathan (2003) argue that physiological changes may lead older CEOs to prefer 'the quiet life', which could bias them away from corporate policies or events that require expending high levels of energy. Financial distress may be considered such an event as it entails several difficult decisions, possibly involving cuts in investment budgets and laying off staff, as well as high pressure from external stakeholders. The prospect of a financially distressed situation may seem particularly unappetizing to an older CEO to the extent they have developed more emotional ties to their firm and loyalties to various individuals in the organization. Stevens, Beyer, and Trice (1978) report empirical evidence that older employees have stronger emotional commitment to their organization. Furthermore, older CEOs tend to be more set in their ways and will avoid taking risks that could disrupt their financial security and social habits (Hambrick and Mason, 1984). These considerations suggest that older CEOs would be more prone to use hedging. In terms of hedging instrument choice, they suggest more frequent use of linear hedging instruments since these reduce variability more than collars and put strategies. In addition, linear instruments afford managers the highest degree of "planning certainty", i.e. the perceived benefits from being able to forecast cash in- and outflows more accurately over a given planning horizon.

In summary, the career risk-hypothesis suggests that younger CEOs prefer more hedging and show a preference for linear instruments, whereas the quiet-life hypothesis suggests that older CEOs

\footnotetext{
${ }^{5}$ Linear hedging instruments are considered more hedging intense because they reduce variability in the payoffdistribution more than do option-based strategies such as collars, as the selected strike prices tend to be higher or lower compared to the prevailing forward price. As the strike prices in a collar strategy approaches the forward price the delta of the collar will converge to that of a forward contract and they will become equivalent forms of risk management. The wider the collar, the lower is the 'hedging intensity' of the position.
} 
prefer more hedging and display a preference for linear instruments. The direction of the effect of CEO age on hedging instrument choice is therefore essentially an empirical issue.

\subsection{Theories based on managerial risk-taking incentives}

As noted in the introduction, Smith and Stulz (1985) were the first to formalize the idea that a firm's hedging decision is influenced by managers' risk incentives. In their theory, managers' expected utility depends on the distribution of the firm's payoffs. Furthermore, managers are risk averse, i.e. their utility is a concave function of end-of-period firm value. Due to this risk aversion, the manager's utility is maximized by hedging completely. For the manager to prefer to bear risk, she must be compensated for doing so by a higher expected income. Shareholders can accomplish this by making the manager's end-of-period wealth a convex function of firm value, for example by implementing bonuses or stock option provisions in the compensation plans.

The insights of Smith and Stulz (1985) can be restated to form a theory about firm's hedging instrument choice. Stated briefly, the theory predicts that convexity in compensation plans ("vega") will bias the manager away from hedging strategies that involve capping the upside potential in the firm's payoff distribution. We will refer to this as the vega theory of hedging instrument choice. To fix ideas on the vega theory, consider first the case of risk-neutral managers with a convex compensation scheme. Such managers prefer no hedging to hedging because it preserves maximum upside. Insurance strategies paid for using cash is preferred to financing the insurance by selling call options (a so-called "collar" strategy) because it preserves more upside. Linear strategies will be the least preferred hedging strategy because it caps upside the most. With risk-averse managers, the observed outcome will reflect the balance between "inherent" risk aversion and the risk-seeking incentives provided by vega. 
While we refer to it as the vega theory of hedging instrument choice for ease of exposition, we should recall that in the theory of Smith and Stulz (1985) the sensitivity of managerial wealth to a change in the underlying firm value ("delta") is of equal importance. In contrast to vega, a high delta is normally assumed to reinforce the incentives of risk averse managers to hedge since a larger portion of their wealth is tied to the development of firm value. Empirically, delta generates predictions that are largely the inverse of vega. ${ }^{6}$

\subsection{Other theories of hedging instrument choice}

Adam (2002) models hedging instrument choice in an inter-temporal setting. In his model, a firm's incentives to use options are a function of its financial status. Financially constrained firms prefer to sell call options in order to finance current investment in real assets. Unconstrained firms, on the other hand, prefer to hedge using an insurance strategy (i.e. buying put options) to protect against the risk of future financing constraints. In this analysis, options emerge as a vehicle for shifting cash across period, and they equalize the marginal value of cash more efficiently than do linear hedging strategies. Adam (2009) finds empirical support consistent with this theory in his investigation of hedging strategies in the North American gold mining industry.

A major conclusion in previous theoretical research on hedging instrument choice is that when the exposures are non-linear, the optimal hedging portfolio contains options (Moschini and Lapan, 1995; Brown and Toft, 2002). This may occur when the magnitude of the exposure is uncertain, e.g. due to production risk, or when this uncertainty is correlated with price risk. However, this theory finds no support in Adam's (2009).

\footnotetext{
${ }^{6}$ That is, delta predicts that CEOs prefer linear hedging, followed by collars and puts, whereas no hedging would be the least preferred alternative.
} 
Finally, hedging instrument choice may be systematically related to financial expertise. Custodio and Metzger (2013) show that financial expertise affects firms' financial policy. They find that firms that have financial experts as CEO hold less cash and use more debt. They are also more responsive to changes in business conditions than firms whose $\mathrm{CEO}$ does not have financial expertise. It can be argued that financial expertise could also affect the decisions regarding if and how a firm implements financial hedging. Given that financial derivatives are inherently complex instruments, financial sophistication could be expected to increase the propensity to use such instruments. This complexity-argument applies particularly to hedging strategies that involve options because the pricing and payoff structure of options is more involved. Thus, higher levels of financial sophistication would therefore be expected to be positively associated with the use of derivatives and the use of options in particular.

\section{Sample, variables, and descriptive statistics}

Our sample consists of US oil and gas firms between the years 2000 and 2008. The oil industry is generally considered ideal for studying corporate hedging because it has significant exposures to a hedgeable risk factor (i.e. the oil price); a great deal of variation in hedge ratios; and sufficiently detailed disclosure with regard to hedging activities (Jin and Jorion, 2006). Firms are eligible for inclusion if they have SIC codes 1311 (oil exploration) or 2911 (petroleum refinement). ${ }^{7} \mathrm{We}$ require that $10-\mathrm{K}$ reports are available from Edgar, and that firms report their derivative positions in sufficient detail to quantify the different hedging strategies. ${ }^{8}$ The latter criterion essentially means that firms must report their hedging position in tabular form. Fortunately a large majority of firms uses this form of disclosure. Firms that report a Value-at-Risk or a sensitivity measure, which are also allowed under US accounting rules, are deleted because the information is insufficient to

\footnotetext{
${ }^{7}$ There are very few firms with SIC-code 2911. Removing these firms from the sample does not alter any of the main results reported in Sections 4 and 5.

${ }^{8}$ Hedging positions are identified by carefully reading the $10-\mathrm{Ks}$, as well as through a keyword search. Examples of search words are: item 7a, "hedg", derivative, market risk, swap, collar, forward, put option, volumetric.
} 
determine the extent and type of hedging strategies. ${ }^{9}$ We furthermore require that data on executive compensation be available in Execucomp in order to calculate delta and vega. Unfortunately, this requirement significantly reduces the number of observations available. In each year, the sample consists of approximately 40 firms. In total, the number of firm-years available is 319 . Financial data are obtained from the COMPUSTAT annual industrial files.

\subsection{Hedging variables}

To represent hedging instrument choice we begin by calculating the nominal positions for each generic hedging strategy identified in our sample; bought put options; sold call options; linear strategies; sold put options; and bought call options. ${ }^{10}$ Of these five, bought puts and linear strategies are the classical risk management strategies in that they give the producing firm protection against falling output prices. Linear strategies involve no upfront cash in- or outflow. Purchases of put options are generally financed with cash-on-hand or by selling call options. The latter is typically referred to as a "collar" strategy, and is a very common strategy in the oil and gas industry (Jin and Jorion, 2006). The firm may also finance the puts by selling puts with a lower strike price. ${ }^{11}$ It only offers the firm downside protection down to the strike specified by the second put. It is thus somewhat speculative, since the firm is in effect betting that the second strike price level will not be reached. The firm may also sell calls in excess of the puts bought. This would tend to generate a positive financing inflow at origination, and can be considered either as a speculative position or as a means of financing investments in real assets (as outlined in Adam, 2002). Bought call is also a speculative strategy in that the firm reinforces its long position in the oil price by creating a financial position that gains if the oil price exceeds a predetermined level.

\footnotetext{
${ }^{9}$ Disclosure of market risks for US companies is regulated by Financial Reporting Release No. 48 ("FRR 48"), issued by SEC in 1997.

${ }^{10}$ Linear strategies refer to hedging strategies for which the payoff is a linear function of the underlying price risk. This category includes swaps, forwards, futures, and sales agreements.

${ }^{11}$ This is sometimes referred to as a "knockout" strategy. The knockout strategy is not mentioned in Adam (2009).
} 
We first create a set of binary variables for describing the different generic hedging strategies without considering whether this is the dominant strategy or not (firms often use two or more of the generic strategies in combination). Linear takes the value 1 if the firm uses a linear hedging strategy in a given year, and zero otherwise. Bought put takes the value 1 if the firm buys put options in a given year, and zero otherwise. Sold put takes the value 1 if the firm sells put options in a given year, and zero otherwise. ${ }^{12}$ Bought call takes the value 1 if the firm buys call options in a given year, and zero otherwise. Sold call takes the value 1 if the firm sells call options in a given year, and zero otherwise.

The generic strategies are first identified by summing the contracts of each type that the firm has in place. The position is thus summed across all years for which the firm has a particular type of derivatives outstanding. For example, if a firm at 2005-12-31 has linear contracts in place for 2006 amounting to 10000 barrels of oil, and 5000 for 2007, the position calculated for the linear strategy is 15 000. If the firm at the same time had a collar position in place for 2006 covering 5000 barrels, but none for 2007 or later, then the position is calculated as 5000 for both puts bought and calls sold.

As complementary measures of hedging we define two additional binary variables. Hedger takes the value 1 if the firm uses financial derivatives in a given year, and zero otherwise. Lost upside takes the value 1 if the firm either uses linear contracts or sells call options. Lost upside is a summary measure targeting whether or not the firm engages in strategies that involve the capping of upside potential.

\footnotetext{
${ }^{12}$ This variable is analyzed outside the multinomial because it has relatively few observations, and overlaps with the other hedging strategies to a large degree.
} 
Following Adam (2009), we evaluate hedging instrument choice using a multinomial logit regression. To maximize the information content the categories in the multinomial are mutually exclusive and based on which hedging strategy is the dominant one (many firms use more than one hedging strategy at the same time). This means that for the linear and collar strategies, a value of 1 is only assigned if that position is larger than the other. For example, if a firm's derivative portfolio consists of $75 \%$ linear instruments and $25 \%$ collars, we will register a one on the former but a zero on the latter. Consequently, Linear dominant takes the value 1 if a) the firm uses linear contracts and b) these contract volumes are larger than those concerning collar strategies. Collar takes the value 1 if a firm a) buys puts and sells calls and b) these contract volumes are larger than those concerning linear strategies. Put only takes the value 1 if the firm exclusively engages in strategies that involve the purchase of put options (i.e. these options are financed with cash-on-hand rather than by selling calls). The Bought call-strategy is ignored in the multinomial because it has too few observations to constitute a meaningful variable. The Sold put-strategy is also excluded from the multinomial logit because it never occurs as a separate, dominant strategy but always in conjunction with a collar.

Again following Adam (2009), for robustness we analyze several variables that describe the relative size of a particular strategy in the firm's overall derivative position. ${ }^{13}$ Extent of insurance is puts divided by the sum of linear contracts and puts. Extent of collar is the lower of puts and calls, divided by the sum of linear contracts and the lower of puts and calls. Extent of selling calls is calls divided by the sum of linear contracts and calls. In addition to these three measures used by Adam (2009), we also define Extent of linear as the number of linear contracts divided by the sum of linear contracts and the larger of puts and calls. ${ }^{14}$

\footnotetext{
${ }^{13}$ In what follows, puts refer to puts bought only. Calls refer to calls sold only.

${ }^{14}$ We use the max of calls and puts to avoid extreme values when the firm uses only a small amount of either puts or calls. When the max is used the value of the variable is bounded at $100 \%$.
} 
Tufano (1996) argues that the "delta percentage" is the most appropriate measure of hedging activity. The delta percentage is calculated as the sensitivity (delta) of the firm's hedging portfolio to a small change in the underlying market risk being hedged, scaled by production. For our purposes, the delta percentage is not suitable because of its sensitivity to market conditions. Because of this sensitivity, the delta percentage may be a poor characterization of hedging instrument choice, especially in a period when the underlying market risk has trended over a period of time. To understand this point, consider that a collar position at inception often is symmetric, so that the premium received from selling calls just offsets the outlay from buying put options. These positions will have similar deltas. However, at a later measurement (fiscal-year end in our case) market movements may have rendered one of the positions deeply in the money (and the other consequently deeply out of the money). If the market tends to go up, as in our sample period, this will create an upward bias on the delta of the call option, and a downward bias on the put option. This may seriously misrepresent the original hedging instrument choice. ${ }^{15}$

\subsection{Risk incentives}

CEO age is the age of the CEO as obtained from Execucomp. To capture compensation-based CEO risk incentives we follow the literature and use delta and vega. The computation of delta and vega follows Guay (1999) and Core and Guay (2002). We use the Black and Scholes option-valuation model (1973) modified to take dividends into account (Merton, 1973). Delta is defined as the dollar change in CEO wealth for a 1\% change in the firm's stock price. Vega is defined as the dollar change in CEO wealth from a $1 \%$ change in the volatility of the firm's stock price. We limit the vega calculation to managers' portfolio of share options. Potentially vega is influenced by the option characteristic of the stock itself, which arises due to the limited liability of shareholders.

\footnotetext{
15 This is evident in the table in Tufano's paper that illustrates the delta-percentage (Table 1). The original collar position hedged 20000 ounces of gold. At measurement, due to market movements, the put option has a delta of -0.957 whereas the call option has a delta of -0.003 . This would practically classify this company as a non-user of the strategy of selling calls.
} 
However, Guay (1999) shows that the contribution to total vega from share vega is very small. In the regression analysis, we use the log of vega and delta to reduce concerns due to asymmetric distribution of these variables.

\subsection{Other variables}

Our control variables are largely drawn from the literatures on managerial risk-taking incentives (e.g. Carter et al, 2006) and corporate hedging (e.g. Adam, 2009). Additional details are provided in the appendix to this paper. Cash compensation is the salary and bonus in the fiscal year. According to Guay (1999) this variable proxies for the degree of diversification on part of the manager since a large cash component means that the managers has more money to invest in assets outside the firm. ${ }^{16}$ Duality is a dummy variable that takes the value 1 if the firm's CEO is also chairman of the board. A CEO that is also the chairman signals entrenchment, which suggest less need for hedging since the manager is at less risk of being replaced in the event of financial distress. Overconfidence is a dummy variable that takes the value 1 when the CEO is identified as overconfident based on a similar methodology as in Malmendier and Tate $(2005,2008)$. In a hedging context, overconfidence could translate into an increased propensity to hedge out of a conviction to "beat the market". Assets is the total assets at fiscal-year-end. Previous research has shown that large firms tend to use derivatives more (e.g. Haushalter, 2000). Capex is the log of the ratio between investment in fixed assets and net property, plant, and equipment. In the literature on corporate hedging, firms that have a high investment rate are normally assumed to have a higher incentive to hedge since shortfalls of internal funds will be relatively more costly (Froot, Scharfstein, and Stein, 1993). Tobin's $Q$ is defined as the sum of the market value of equity and the book value of debt, divided by the book value of assets. Similar to the investment rate, this variable suggests more attractive investment opportunities and a higher cost of cash shortfalls (and by extension a higher propensity to hedge).

\footnotetext{
${ }^{16}$ Alternatively, a compensation that is insensitive to corporate performance signals managerial entrenchment (Berger, Ofek, and Yermack, 1997).
} 
Leverage is total debt scaled by total assets. Highly leveraged firms are usually considered to have higher expected costs of financial distress, which provides an incentive to use hedging (Smith and Stulz, 1985). Dividend dummy is a dummy that takes the value 1 if the firm pays a cash dividend. This variable is typically used as a measure of access to capital markets, on the logic that firms that are financially constrained would be reluctant to pay a dividend (Fazzari, Hubbard, and Pedersen, 1988). Since firms with capital markets access can replace internal cash flow with external cash flow, they have less need for hedging. Proved reserves is a measure of the amount of oil and gas owned by the firm that can be economically recovered. It can be viewed as a proxy for the collateral value of the firm's assets. Firms with high proved reserves should enjoy better access to capital markets and therefore have less need for hedging. Firms with Cash reserves is defined as cash and cash equivalents scaled by assets. Having a buffer of cash is an alternative form of risk management that, other things equal, lowers the need for corporate hedging. Following Coles et al. (2006) we use CEO tenure (Tenure) as additional control for CEO entrenchment. Finally, the proxy for financial sophistication is financial expertise. Financial expertise is a binary variable that takes the value one if the CEO has past experience in a financial institution, or in finance or accounting. ${ }^{17}$

\subsection{Descriptive statistics}

Table 1 presents summary statistics for CEO age (panel A) and Vega (panel B) for each year between 2000 and 2008. As can be seen from Table 1, CEO age remained largely constant throughout the sample period. The mean (55 years) and median (54.5 years) values are very similar to those reported in Yim (2013). The standard deviation of CEO age is above 7 years, which suggests that $95 \%$ of the CEOs are between 40 and 69 years of age, fairly reasonably values. The magnitude of the standard deviation also assures us that there is indeed meaningful variation in the CEO age variable. For vega there is a sharp decrease after 2004. Beginning in 2004 vega

\footnotetext{
${ }^{17}$ In an untabulated analysis we use financial education (a binary variable that takes the value one if the CEO has an MBA or other degree in economics, finance, or accounting) instead of financial expertise. Results are qualitatively similar to those reported and are therefore omitted for the sake of brevity.
} 
experienced two exogenous shocks that together caused its average value to decline by more than a third by 2007. The first shock was the introduction of new rules concerning the expensing of employee stock options (FAS 123R). FAS 123R made the expensing of employee options mandatory, which reduced their attractiveness as a form of executive compensation (Hayes et al, 2012). While FAS 123R became effective in June 2005, firms began accelerating their previously vested option grants already in October 2004 when FASB issued a decision that such accelerated vesting would not lead to an earnings charge (Ladika and Sautner, 2013). The other shock to vega came about as a consequence of the sharply increasing oil prices beginning in 2004. In that year the oil price started a relentless march upward that was to continue until the last quarter of 2008 . The oil price successively reached new record levels, peaking at a quarterly average of $\$ 122$ in the second quarter of 2008 , compared to a previous high of $\$ 36$ in the pre-2004 period (in 2000). The average oil price between 2005 and 2008 were $\$ 72$, compared to $\$ 28$ in the years $2000-2003 .{ }^{18}$ The implication for vega from this shock was that a large number of share options were exercised by managers, and those that were kept ended up deep in-the-money. Both these facts served to reduce vega.

\section{[INSERT TABLE 1 ABOUT HERE]}

Table 2 reports summary statistics for the hedging variables. Table 2 shows that derivatives are used in $83 \%$ of firm-years. This is a similar percentage as in Jin and Jorion (2006), who identify $81 \%$ of firms as derivative users. At above $50 \%$, the usage of options is much higher than in Haushalter (2000), who reports that around $10 \%$ of his sample of oil and gas firms use options. Two explanations for this stand out. The first is that option usage has continued to grow over time (Haushalters sample covers the years 1992-1994). The second is that the average size of firms in our sample is larger than in the one used by Haushalter (2000), whose sample consists of 100 firms.

\footnotetext{
${ }^{18}$ See Jankensgård and Andrén (2013) for an analysis of the impact on the oil and gas industry from this price increase.
} 
Larger firms are known to be more frequent users of hedging. Of the more speculative strategies, selling put options is the most common, occurring in $10 \%$ of firm-years. Buying call options occurs infrequently (1\%). Table 2 also shows that the collar strategy is a very common strategy in the oil and gas industry. The average hedging portfolio consists of $46.2 \%$ collars. That the percentages on Extent of insurance and Extent of selling calls are similar to the Extent of collar indicates that the former strategies are rarely used in isolation. The strategy of using linear instruments is the most common (49.6\% of the average hedging portfolio is made up of linear contracts). ${ }^{19}$

\section{[INSERT TABLE 2 ABOUT HERE]}

Table 3 reports the mean and median of the four main categories of firms investigated in this paper: Non-Hedgers, Put only, Collar, and Linear Dominant (panel A). Panel B reports the p-values of the test of differences in the mean and median values where the base category is Linear.

\section{[INSERT TABLE 3 ABOUT HERE]}

\section{Results}

\subsection{Determinants of the decision to hedge}

In this section we analyze the determinants of the decision to hedge. Table 4 reports the results from estimating a probit model where the dependent is Hedger (Model I). Table 4 also reports the results from probit estimations of the likelihood of using a linear hedging strategy (Linear Base, Model II); using a hedging strategy that involves the capping of upside potential (Lost Upside, Model III) and the probability of using a strategy of selling put options (Sold Put, Model IV); the strategy of buying puts (Bought put, Model V); and the strategy of selling call options (Sold Call, Model VI).

\footnotetext{
${ }^{19}$ The remainder of the average hedge portfolio is thus around $4 \%$, which is largely made up of "pure" insurance strategies, i.e. those that do not involve any selling of calls.
} 


\section{[INSERT TABLE 4 ABOUT HERE]}

Table 4 indicates that CEO age is negatively associated with the decision to hedge, and to the decision to use linear hedging strategies. These results are significant at the $10 \%$ and $1 \%$ levels respectively (Panel A). This gives some early indications in support of the career risk-hypothesis discussed in Section 2. Vega is negatively associated with the decision to use derivatives, consistent with the prediction of the vega theory, according to which high-vega managers prefer to remain unhedged because this strategy preserves maximum upside potential. Also consistent with the theory, vega appears to be negatively related to hedging strategies that involve the selling of call options.

The coefficients in Model 1 are comparable to a large literature studying the determinants of corporate hedging. According to Model 1 the decision to hedge is positively related to size, which is consistent with previous research (see Jankensgård, 2014). The coefficient on Tobin’s Q is positive, indicating that firms that investors award a higher valuation are associated with more hedging. Such an association has been identified in the majority of previous studies (e.g. Allayannis and Weston, 2001). Cash reserves are negatively correlated with the hedging decision, supporting the idea that cash holdings are an alternative way of managing risk which reduces the need for financial derivatives. Overconfidence has a negative coefficient, which contradicts the notion that overconfident managers are more prone to use derivatives speculatively. Cash compensation too has a negative coefficient, suggesting that well-diversified managers engage less in hedging. ${ }^{20}$ The coefficient on proved reserves is negative, consistent with an interpretation that reserves increases

\footnotetext{
${ }^{20}$ Even if cash compensation is taken to represent managerial entrenchment the result is consistent: more entrenched managers have less need to hedge because they are less exposed to the risk of being fired.
} 
the collateral value of assets and thus less need for hedging. Only the negative sign on Capex is contrary to expectations.

\subsection{Determinants of derivative instrument choice}

In this section we analyze if hedging instrument choice is explained by CEO age and compensationbased risk-incentives. Table 5 reports the result from a set of multinomial logit regressions. Again, these variables differ from those reported in Table 4 in that they constitute dominant strategies, meaning they make up $50 \%$ or more of the total derivative position. In Model 1 the dependent variables are No hedging, Put only, Linear dominant, and Collar. The base case is No hedging. In Model 2 the No hedging and Put only categories are dropped an instead Collar is the base. This is done to compare more directly the two main hedging strategies in the oil and gas industry (Linear and Collar).

\section{[INSERT TABLE 5 ABOUT HERE]}

In Model 1 in Table 5 we see that CEO age is negatively related to Linear dominant (significantly at the 5\%-level). In Model 2 we again obtain that the use of linear hedging strategies is negatively and significantly related to CEO age. These results strongly suggest that firms with younger CEOs are more likely to employ a linear hedging strategy. This is in keeping with the career risk-hypothesis from section 2, but is inconsistent with the quiet life-hypothesis. It should be noted that we obtain these results controlling for the possibility that younger CEO's, on account of a higher financial sophistication and openness to complex hedging arrangements, tend towards more sophisticated hedging strategies, i.e. those involving options.

Reflecting that firms with high-vega managers tend to hedge less, Model 1 shows that vega is negatively related to collar strategies. However, in Model 2, comparing linear vs. collar strategies, 
we see that a higher vega increases the likelihood of choosing a linear strategy. The latter finding is inconsistent with the prediction of the vega theory, which holds that, since they surrender the most upside potential, high-vega managers would eschew linear hedging strategies.

For robustness, following Adam (2009), Table 6 reports the results from random effects tobit models. The dependent variables are Extent of insurance (Model I); Extent of selling calls (Model II); Extent of collar (Model III); and Extent of linear (IV). With regard to CEO age the results are consistent with the ones from the multinomial logit: CEO age is positively related to the extent of linear strategies, and negatively to the extent of option-based strategies. These results reinforce the conclusions in the multionomial logit: CEO age is negatively related to the size of the linear positions used in relation to the firm's overall derivative portfolio. Vega does not reach significance at conventional levels in any of the regressions presented in Table 6.

\section{[INSERT TABLE 6 ABOUT HERE]}

As a further robustness check we allow Sold call dominant to enter the multinomial reported in Table $5 .^{21}$ Sold call dominant takes the value 1 if the firm sells call in excess of the amount of puts bought in a regular collar. The results with regard to CEO age and the use of a linear hedging strategy are unaffected by this change in the model specification. Further support for the importance of CEO age as a determinant of hedging instrument choice come from untabulated regressions in which we deflate the number or linear contracts with the firm's production (expressed as the number of barrels of oil equivalents produced in the fiscal year). CEO age is again significant (at the $10 \%$-level) with a negative sign, indicating that younger CEOs are more inclined to use this hedging strategy.

\footnotetext{
${ }^{21}$ All untabulated results in this paper are available from the authors upon request.
} 
The results reported in this section lend no clear support to the hypothesis that hedging instrument choice is driven by financial status (as outlined in Adam, 2002). Indicators of financial status leverage, dividends and cash - generally lack explanatory power. ${ }^{22}$

\subsection{CEO age and investments in real assets}

Considered in isolation, our findings on CEO age appear to suggest that younger managers are more risk averse. We have posited that a concern about career risk could bring about a risk-averse behavior. However, the notion that younger CEOs are more risk averse seems to contradict some recent findings with regard to the effect of CEO age and risk-taking in real assets. Two recent studies find a positive relation between CEO age and various indicators of corporate risk-taking (Yim, 2013, Serfling, 2014). One way to reconcile these findings with our results is simply to argue that financial hedging and risk-taking in real assets measure different aspects of risk, and managers can have different degrees of risk tolerance to different types of risk. For example, managers may display a risk-loving behavior when it comes to acquisitions because the permanent increase in salary that accompanies them tends to overwhelm any disutility from a higher firm risk from the acquisition (as outlined in Yim, 2013). For financial hedging, however, the disutility to the manager from a financially distressed situation may exceed any benefit derived from remaining unhedged.

Another way to reconcile our findings with those of Yim (2013) and Serfling (2014) is to argue that younger CEOs tend to use more financial hedging because they take more risk in terms of real assets. To investigate this complementarity-argument we replace financial hedging as the dependent variable with various proxies for real risk-taking (exploration expense, capital expenditure, and

\footnotetext{
${ }^{22}$ In untabulated regressions we include the category Sold call dominant, which takes the value 1 if the firm sells call in excess of the amount of puts bought in a regular collar. This strategy therefore identifies "excessive" sales of call options, which generally leads to a positive cash inflow at inception (prior to considering the eventual payoffs from the hedging portfolio). Cash reserves are positively related to this strategy. While high cash holdings certainly do not unambiguously signal the absence of financial constraints, this result contradicts that selling calls is motivated by lack of liquid resources.
} 
acquisitions). The results are reported in Table 7. The results do not support the existence of complementarity. CEO age is not significant in explaining any of the three proxies for risk-taking in real assets.

\section{[INSERT TABLE 7 ABOUT HERE]}

\section{Alternative explanations and endogeneity}

\subsection{The increase in oil price during the 2005-2008 period}

As previously discussed, in 2004 the oil prices began a sharp upward climb that would last to the last quarter of 2008. In a relatively short time-span, oil prices rose to levels that would have been unthinkable to managers only a couple of years earlier. Forward markets just prior to the price increase gave no indications that such a massive increase in the oil price was about to happen. This price increase had many consequences for the firms and managers in the industry, and such a turn of events could potentially alter their hedging behavior. Figure 1 illustrates how hedging instrument choice evolved over the sample period.

\section{[INSERT FIGURE 1 ABOUT HERE]}

Figure 1 suggests that collar strategies increased at the expense of linear strategies after the shock. To explain this shift, we note that the average financial distress risk of in the industry indeed came down significantly as the cash generation improved and conditions in the financial markets were very favorable to oil firms (Jankensgård and Andrén, 2013). With less financial distress risk managers presumably could concentrate on establishing downside protection using put options with strike prices below the forward rate, and if they believed prices were at unsustainable levels and 
more likely to come down that continue up, selling calls would have appeared as a cheap way to finance the put options.

Table 8 investigates whether determinants of the decision to hedge and to employ a linear hedging strategy were different depending on which sub-period is chosen. To this end, we interact $\ln (\mathrm{Vega})$, $\ln$ (Delta), and $\ln$ (Age) with Post 2004, a binary variable that takes value one after 2004 . We employ a linear probability model estimated with OLS. ${ }^{23}$ The results support the notion that the sample period matters. Age is negatively related both to the decision to hedge and the decision to use a linear hedging instrument. However, the interaction coefficient is positive and significant. These results are consistent with the hypotheses presented in this paper. If differing attitudes to the consequences of financial distress is influencing hedging behaviour, we would expect the difference between younger and older CEOs to become less in periods of falling risk of financial distress.

Another consequence of the regime shift in the oil market was that vega sharply decreased. This happened because managers exercised a large number of options and those still held became deeply in-the-money (see section 3.4). In 2005-2006 vega dropped by almost a third compared to its pre2004 levels, implying a major shock to risk incentives. For vega, however, the results are similar in both sub-periods.

\section{[INSERT TABLE 8 ABOUT HERE]}

\footnotetext{
${ }^{23}$ In models such as probit and logit models, the coefficient of interaction variables indicate the direction of the effect (Puhani, 2012, Ai and Norton, 2003), but the estimated magnitude is not reliable.
} 


\subsection{Instrument Variable approach}

Similarly to Serfling (2014), we use the natural logarithm of the Consumer Price Index (CPI) in the year when the CEO was born (Ln CPI at Birth) to mitigate endogeneity concerns. ${ }^{24}$ Indeed, it is not possible to rule out that a time-variant omitted variable or a variable related to specific types of firms hiring CEOs of certain ages drives the negative relation between CEO age and financial hedging. The arguments in favor of using Ln CPI at Birth as instrument for age are clearly stated by Serfling (2014). The variable has a strong negative correlation with CEO age, ${ }^{25}$ and it is very unlikely that the CPI in the year when the CEO was born is correlated with current firm hedging policy, except through its relation with the CEO's age. Table 9 reports the results of the instrument variable approach. In Panel A, we report the second-stage results of IV probit models for the likelihood of being a hedger and employing a linear hedging strategy. The instrumented age variable is significant and with the expected negative coefficient. Panel B shows the second-stage results of a multinomial logit model for the decision to select a particular hedging strategy. The four strategies we consider are: no hedging; put only; collar (put \& call); and linear. The base category is no hedging. Ln(Age) is instrumented by the log of CPI at birth, which is the consumer price index in the year the CEO was born. The first-stage regression regress $\ln (\mathrm{Age})$ on $\ln (\mathrm{CPI}$ at birth), the instrument, and the control variables listed in the table. In column I, we use the predicted value of the first stage regression as instrument, obtaining a negative and significant coefficient for the linear strategy. In Column II, we include the original age variable and the residuals of the first stage regressions. Following the Rivers and Vuong (1988) approach, a significant coefficient for the residuals would mean that the correlation of the errors among the two regressions (the first and the second stage regressions) is significant and the endogeneity problem is highly relevant. While the log of age remains negative and highly significant for the linear strategy, we do not find significant

\footnotetext{
${ }^{24}$ Consumer Price Index data (Consumer Price Index - All Urban Consumers ) are from the Bureau of Labor Statitistics. US Department of Labor.

${ }^{25}$ We find evidence of this negative and significant relationship in all the first-stage regressions, whose results are untabulated for sake of brevity.
} 
coefficients for the residuals, alleviating endogeneity concerns. Panel C presents estimates of random effects Tobit model regressions evaluating the determinants of the extent of choosing different options strategies. In these models, the predicted values of $\operatorname{Ln}($ Age) from the first-stage regression is used in the regressions instead of $\ln$ (Age). Results closely mirror those in Table 6. Finally, in Panel D, we replicate Table 7 using IV OLS regressions. Results for real corporate investments are also similar to those presented in the main analysis.

\section{[INSERT TABLE 9 ABOUT HERE]}

\subsection{Long-tenured CEOs}

As discussed in the previous section, the age-hedging relation may reflect the selection of young CEOs by firms that want to hedge, instead of the decisions of young CEOs. To put it another way, firms that prefer a higher derivatives usage may decide to appoint a young CEO. As argued by Yim (2013), this effect should be more pronounced in the years close to the hiring. Therefore, in Table 10 we exclude observations where the CEO has three or fewer years of tenure to verify whether the effect persists. Both Panel A (probability of using a certain hedging strategy) and Panel B (extent of using hedging strategies) show that the relation between age and hedging persists even if we consider only long-tenured CEOs.

[INSERT TABLE 10 ABOUT HERE]

\section{Conclusions}

In this paper we add to the literature on how firm's hedge. Previous empirical research on hedging instrument choice has only tested theories related to firm's financial status and production uncertainty. We investigate two dimensions of managerial risk preferences: CEO age and risk 
incentives as provided by managers' compensation plans (measured by vega). In our empirical analysis we benefit from a unique, hand-collected dataset of hedging positions in the US oil and gas industry between 2000 and 2008 .

The data provides strong support of CEO age as a determinant of hedging strategies, but only mixed support for the vega theory of hedging instrument choice. The evidence suggests that younger CEOs are more likely to hedge, and to prefer linear hedging strategies. We carry out an IVapproach and reach similar conclusions. In fact, the results are robust across a large set of model specifications and definitions of hedging instrument choice.

The findings presented in this paper may seem to run counter to the general perception of young CEOs as more prone to take risks, as well as recent research suggesting the same. We investigate a potential way to reconcile our findings with this view, namely that younger CEOs use financial hedging more because they are more active risk-takers when it comes to real assets. The evidence does not bear out the complementarity-hypothesis. Though more research is needed on the connection between real and financial risk-taking at the CEO-level, we believe a more promising path is to carefully analyze differences in CEO incentives related to different types of risk-taking. Whereas younger CEOs have relatively stronger incentives to, say, make acquisitions and benefit from the associated pay-rise, younger managers are also more incentivized to hedge against the risk of financial distress. Since financial distress sends a negative signal of managerial ability, younger CEOs have a greater incentive to avoid it because they suffer the consequences of such a signal over a longer career-horizon. 


\section{References}

Adam, T., 2009. Capital expenditures, financial constraints, and the use of options. Journal of Financial Economics 92, 238-251

Adam, T.R., 2002. Risk management and the credit risk premium. Journal of Banking \& Finance 26,243

Allayannis, G., Weston, J.P., 2001. The Use of Foreign Currency Derivatives and Firm Market Value. The Review of Financial Studies 14, 243-276

Ai, C., Norton, E.C., 2003, Interaction terms in logit and probit models, Economics Letters 80, 123129.

Berger, P.G., Ofek, E., Yermack, D.L., 1997. Managerial entrenchment and capital structure decisions. Journal of Finance 52, 1411-1438

Bodnar, G.M., Hayt, G.S., Marston, R.C., 1998. 1998 Wharton survey of financial risk management by US non-financial firms. FM: The Journal of the Financial Management Association 27, 70

Brown, G.W., Toft, K.B., 2002. How Firms Should Hedge. The Review of Financial Studies, 1283

Coles, J., Daniel, N., Naveen, L., 2006. Managerial incentives and risk-taking. Journal of Financial Economics 79, 431-468.

Core, J. E., Guay, W. R., 2002. Estimating the value of employee stock option portfolios and their sensitivities to price and volatility. Journal of Accounting Research 40, 613-630.

Chevalier, J., Ellison, G., 1999. Career concerns of mutual fund managers. Quarterly Journal of Economics 114, 389-432.

Fazzari, S.M., Hubbard, R.G., Petersen, B.C., Blinder, A.S., Poterba, J.M., 1988. Financing Constraints and Corporate Investment. Brookings Papers on Economic Activity 1988, 141206

Froot, K.A., Scharfstein, D.S., Stein, J.C., 1993. Risk Management: Coordinating Corporate Investment and Financing Policies. Journal of Finance 48, 1629-1658

Guay, W., 1999. The sensitivity of CEO wealth to equity risk: an analysis of the magnitude and determinants. Journal of Financial Economics 53, 43-71.

Hambrick, D.C., Mason, P.A., 1984. Upper Echelons: The Organization as a Reflection of Its Top Managers. Academy of Management Review 9, 193-206

Haushalter, G.D., 2000. Financing Policy, Basis Risk, and Corporate Hedging: Evidence from Oil and Gas Producers. The Journal of Finance 55, 107-152

Hayes, R. M., Lemmon, M., Qiu, M., 2012. Stock options and managerial incentives for risk taking: evidence from FAS 123R. Journal of Financial Economics 105, 174-190.

Hirshleifer, D., Thakor, A. V., 1992. Managerial conservatism, project choice and debt, Review of Financial Studies 5, 437-470.

Hirshleifer, D. A., Low, A., Teoh, S. H., 2012. Are overconfident CEOs better innovators? Journal of Finance 67, 1457-1498.

Holmstrom, B., 1999. Managerial incentive problems: a dynamic perspective. Review of Economic Studies 66, 169-182.

Jankensgård, H., 2014. Does centralisation of FX derivative usage impact firm value? European Financial Management, forthcoming

Jankensgård, H. and N. Andrén, 2013. Wall of Cash: The investment-cash flow sensitivity when capital becomes abundant. Knut Wicksell Centre for Financial Studies working paper series.

Jin, Y., Jorion, P., 2006. Firm Value and Hedging: Evidence from U.S. Oil and Gas Producers. The Journal of Finance, 893

Knopf, J. D., Nam, J., Thornton Jr. J. H., 2002. The volatility and price sensitivities of managerial stock option portfolios and corporate hedging. Journal of Finance 57, 801-813.

Ladika, T., and Sautner, Z., 2013. The Effect of Managerial Short-Termism on Corporate Investment. Working paper, University of Amsterdam. 
Lewellen, K., 2006. Financing decisions when managers are risk averse. Journal of Financial Economics 82, 551-589

Malmendier, U., Tate, G. A., 2005. CEO overconfidence and corporate investment. Journal of Finance 60, 2661-2700.

Malmendier, U., Tate, G. A., 2008. Who makes acquisitions? CEO overconfidence and the market's reaction. Journal of Financial Economics 89, 20-43.

Merton, R. 1973. Theory of rational option pricing, Bell Journal of Economics and Management Science, 4 (1), 141-183.

Moschini, G., Lapan, H., 1995. The Hedging Role of Options and Futures Under Joint Price, Basis, and Production Risk. International Economic Review, 1025

Puhani, P. A., 2012, The treatment effect, the cross difference, and the interaction term in nonlinear "difference-indifferences" models, Economics Letters 115, 85-87.

Rajgopal, S., Shevlin, T., 2002. Empirical evidence on the relation between stock option compensation and risk taking. Journal of Accounting and Economics 33, 145-171.

Rivers, D., and Vuong Q. H., 1988. Limited information estimators and exogeneity tests for simultaneous probit models. Journal of Econometrics 39, 347-66

Serfling, M.A., 2014. CEO age and the riskiness of corporate policies. Journal of Corporate Finance, 25, 251-273.Scharfstein, D.S., Stein, J.C., 1990. Herd behavior and investment. American Economic Review 80, 465-479

Smith, C.W., Stulz, R.M., 1985. The Determinants of Firms' Hedging Policies. Journal of Financial \& Quantitative Analysis 20, 391-405

Stevens, J.M., Beyer, J.M., Trice, H.M., 1978. Assessing Personal, Role, and Organizational Predictors of Managerial Commitment. Academy of Management Journal 21, 380-396

Taylor, R.N., 1975. Age and Experience as Determinants of Managerial Information Processing and Decision Making Performance. Academy of Management Journal 18, 74

Tufano, P., 1996. Who Manages Risk? An Empirical Examination of Risk Management Practices in the Gold Mining Industry. The Journal of Finance 51, 1097-1137

Yim, S. 2013. The acquisitiveness of youth: CEO age and acquisition behavior. Journal of Financial Economics 108, 250-273 
Table 1 - CEO Age \& Vega

Panel A reports the mean, median, and standard deviation of CEO age by year. Panel B reports the same statistics for Vega (in US\$ million). Variable definitions are provided in Appendix A.

Panel A: CEO Age

\begin{tabular}{ccccc}
\hline Year & Mean & Median & Standard Deviation & \# Observations \\
\hline 2000 & 55.56 & 54.00 & 8.50 & 48 \\
2001 & 54.64 & 53.50 & 7.61 & 44 \\
2002 & 54.22 & 53.00 & 6.32 & 46 \\
2003 & 54.22 & 54.00 & 7.18 & 46 \\
2004 & 56.05 & 56.00 & 6.64 & 35 \\
2005 & 56.40 & 57.00 & 6.52 & 43 \\
2006 & 55.23 & 55.00 & 6.73 & 50 \\
2007 & 54.69 & 54.50 & 7.38 & 402 \\
2008 & 55.22 & 55.00 & 7.23 & \\
\hline
\end{tabular}

Panel B: Vega

\begin{tabular}{ccccc}
\hline Year & Mean & Median & Standard Deviation & \# Observations \\
\hline 2000 & 0.1610 & 0.0605 & 0.2362 & 48 \\
2001 & 0.1928 & 0.0787 & 0.2853 & 45 \\
2002 & 0.1718 & 0.0631 & 0.2770 & 46 \\
2003 & 0.1783 & 0.0585 & 0.2838 & 47 \\
2004 & 0.1943 & 0.0715 & 0.2979 & 42 \\
2005 & 0.1542 & 0.0506 & 0.2530 & 43 \\
2006 & 0.1356 & 0.0317 & 0.2419 & 48 \\
2007 & 0.1171 & 0.0309 & 0.1960 & 50 \\
2008 & 0.1493 & 0.0269 & 0.2766 & 404 \\
& & & & \\
\hline
\end{tabular}




\section{Table 2 - Descriptive Statistics for Hedging Variables}

The table reports the mean, median, and standard deviation of hedging variables. Variable definitions are provided in Appendix A.

\begin{tabular}{lccc}
\hline \multicolumn{1}{c}{ Year } & Mean & Median & \# Observations \\
\hline Hedger & & & 319 \\
Linear & 0.8276 & 1.0000 & 319 \\
Lost Upside & 0.3668 & 0.0000 & 319 \\
Sold Put & 0.7931 & 1.0000 & 319 \\
Bought Call & 0.1066 & 0.0000 & 319 \\
Bought Put & 0.0125 & 0.0000 & 319 \\
Sold Call & 0.6176 & 1.0000 & 319 \\
Extent of Insurance & 0.5768 & 1.0000 & 253 \\
Extent of Selling Calls & 0.4917 & 0.5477 & 253 \\
Extent of Collar & 0.4737 & 0.4995 & 253 \\
Extent of Linear & 0.4618 & 0.4748 & 253 \\
& 0.4963 & 0.4462 & \\
\hline
\end{tabular}


Table 3 - Descriptive Statistics by Dominant Strategy.

Panel A reports the mean, and median of variables used in the analysis by the dominant hedging strategy used by the firm in a given year. Panel B presents the pvalues of the tests for differences in mean and of the median tests between Linear and the other strategies. Variable definitions are provided in Appendix A.

Panel A: Means and Medians

\begin{tabular}{|c|c|c|c|c|c|c|c|c|c|c|c|c|}
\hline \multirow[b]{3}{*}{ Vega } & \multicolumn{3}{|c|}{ Non Hedgers } & \multicolumn{3}{|c|}{ Put Only } & \multicolumn{3}{|c|}{ Collar (put \& Call) } & \multicolumn{3}{|c|}{ Linear } \\
\hline & Mean & Median & $\mathrm{N}$ & Mean & Median & $\mathrm{N}$ & Mean & Median & $\mathrm{N}$ & Mean & Median & $\mathrm{N}$ \\
\hline & 0.120 & 0.026 & 55 & 0.034 & 0.023 & 11 & 0.101 & 0.034 & 129 & 0.092 & 0.043 & 117 \\
\hline Delta & 0.598 & 0.248 & 53 & 0.296 & 0.141 & 11 & 0.584 & 0.307 & 124 & 1.026 & 0.321 & 108 \\
\hline Age & 58.222 & 56.500 & 54 & 52.909 & 51.000 & 11 & 54.969 & 54.000 & 128 & 52.573 & 52.000 & 117 \\
\hline Total Assets & 4570.2 & 805.5 & 55 & 1293.2 & 1083.5 & 11 & 8713.8 & 3187.7 & 129 & 4660.0 & 2132.3 & 117 \\
\hline Proved Reserves & 329273.8 & 45202.0 & 37 & 104158.1 & 81439.5 & 10 & 300369.0 & 92871.0 & 124 & 169322.2 & 88122.5 & 100 \\
\hline Cash Compensation & 1362.3 & 770.0 & 55 & 1000.4 & 850.1 & 11 & 1438.0 & 1047.1 & 129 & 1474.1 & 836.8 & 117 \\
\hline Leverage & 0.173 & 0.156 & 55 & 0.284 & 0.298 & 11 & 0.262 & 0.255 & 129 & 0.289 & 0.293 & 117 \\
\hline Dummy Dividends & 0.473 & 0.000 & 55 & 0.182 & 0.000 & 11 & 0.612 & 1.000 & 129 & 0.598 & 1.000 & 117 \\
\hline Tobin Q & 1.487 & 1.415 & 53 & 1.475 & 1.268 & 11 & 1.346 & 1.268 & 128 & 1.550 & 1.456 & 115 \\
\hline Cash Reserves & 0.092 & 0.064 & 55 & 0.048 & 0.005 & 11 & 0.034 & 0.015 & 129 & 0.034 & 0.009 & 117 \\
\hline CEO/Chairman & 0.400 & 0.000 & 55 & 0.545 & 1.000 & 11 & 0.481 & 0.000 & 129 & 0.521 & 1.000 & 117 \\
\hline Overconfidence & 0.727 & 1.000 & 55 & 0.455 & 0.000 & 11 & 0.612 & 1.000 & 129 & 0.641 & 1.000 & 117 \\
\hline Capex/PPE & 0.309 & 0.298 & 55 & 0.275 & 0.245 & 11 & 0.250 & 0.231 & 129 & 0.285 & 0.274 & 116 \\
\hline Tenure & 6.491 & 5.000 & 55 & 4.909 & 4.000 & 11 & 6.469 & 5.000 & 128 & 7.619 & 6.000 & 113 \\
\hline Financial Education & 0.362 & 0.000 & 47 & 0.636 & 1.000 & 11 & 0.488 & 0.000 & 125 & 0.573 & 1.000 & 117 \\
\hline Financial Expert & 0.313 & 0.000 & 48 & 0.000 & 0.000 & 11 & 0.328 & 0.000 & 125 & 0.444 & 0.000 & 117 \\
\hline Bought Put & 0.000 & 0.000 & 55 & 3092.740 & 912.500 & 11 & 12976.050 & 6610.274 & 129 & 1386.921 & 0.000 & 117 \\
\hline Sold Call & 0.000 & 0.000 & 55 & 0.000 & 0.000 & 11 & 32611.500 & 5961.546 & 129 & 1678.003 & 0.000 & 117 \\
\hline Linear & 0.000 & 0.000 & 55 & 0.000 & 0.000 & 11 & 3634.618 & 467.416 & 129 & 12918.810 & 6501.542 & 117 \\
\hline Sold Put & 0.000 & 0.000 & 55 & 0.000 & 0.000 & 11 & 3605.392 & 0.000 & 129 & 302.540 & 0.000 & 117 \\
\hline Bought Call & 0.000 & 0.000 & 55 & 0.000 & 0.000 & 11 & 130.422 & 0.000 & 129 & 1.401 & 0.000 & 117 \\
\hline Extent of insurance & & & & & & & 0.833 & 0.881 & 129 & 0.105 & 0.000 & 117 \\
\hline Extent of selling calls & & & & & & & 0.820 & 0.876 & 129 & 0.113 & 0.000 & 117 \\
\hline Extent of collar & & & & & & & 0.814 & 0.872 & 129 & 0.102 & 0.000 & 117 \\
\hline Extent of linear & & & & & & & 0.160 & 0.110 & 129 & 0.884 & 1.000 & 117 \\
\hline
\end{tabular}


Panel B: P-values of Mean and Median Tests of Linear vs. Other categories.

\begin{tabular}{|c|c|c|c|c|c|c|}
\hline \multirow[t]{2}{*}{ Linear vs. } & \multicolumn{2}{|c|}{ Non Hedgers } & \multicolumn{2}{|c|}{ Put Only } & \multicolumn{2}{|c|}{ Collar (Call \& Put) } \\
\hline & Mean & Median & Mean & Median & Mean & Median \\
\hline Vega & 0.4573 & 0.1020 & 0.0022 & 0.5280 & 0.6673 & 0.2020 \\
\hline Delta & 0.0408 & 0.3420 & 0.0008 & 0.0620 & 0.0266 & 0.6930 \\
\hline Age & 0.0000 & 0.0000 & 0.8816 & 0.7180 & 0.0020 & 0.1650 \\
\hline Total Assets & 0.9407 & 0.0220 & 0.0000 & 0.0580 & 0.0012 & 0.1260 \\
\hline Proved Reserves & 0.1284 & 0.7390 & 0.0852 & 0.7400 & 0.0077 & 0.6870 \\
\hline Cash Compensation & 0.6492 & 0.7440 & 0.0776 & 1.0000 & 0.8439 & 0.1580 \\
\hline Leverage & 0.0000 & 0.0000 & 0.9121 & 1.0000 & 0.1201 & 0.0740 \\
\hline Dummy Dividends & 0.1277 & & 0.0067 & & 0.8220 & \\
\hline Tobin Q & 0.3959 & 0.5070 & 0.6004 & 1.0000 & 0.0004 & 0.0090 \\
\hline Cash Reserves & 0.0000 & 0.0000 & 0.5522 & 1.0000 & 0.9462 & 0.1260 \\
\hline CEO/Chairman & 0.1380 & 0.1860 & 0.8857 & . & 0.5252 & 0.6100 \\
\hline Overconfidence & 0.2539 & & 0.2767 & & 0.6445 & \\
\hline Capex/PPE & 0.3236 & 0.4790 & 0.7388 & 0.9780 & 0.0190 & 0.0850 \\
\hline Tenure & 0.2378 & 0.6530 & 0.0175 & 0.2980 & 0.1266 & 0.1700 \\
\hline Financial Education & 0.0143 & & 0.6953 & & 0.1887 & \\
\hline Financial Expert & 0.1103 & 0.1640 & 0.0000 & 0.0110 & 0.0637 & 0.0840 \\
\hline Bought Put & 0.0001 & 0.0000 & 0.3159 & 0.0010 & 0.0000 & 0.0000 \\
\hline Sold Call & 0.0001 & 0.0000 & 0.0001 & 0.0080 & 0.0388 & 0.0000 \\
\hline Linear & 0.0000 & 0.0000 & 0.0000 & 0.0020 & 0.0000 & 0.0000 \\
\hline Sold Put & 0.0520 & 0.2060 & 0.0520 & 0.9810 & 0.0086 & 0.0010 \\
\hline Bought Call & 0.3194 & 0.6980 & 0.3194 & 0.1380 & 0.1529 & 0.6850 \\
\hline Extent of insurance & & & & & 0.0000 & 0.0000 \\
\hline Extent of selling calls & & & & & 0.0000 & 0.0000 \\
\hline Extent of collar & & & & & 0.0000 & 0.0000 \\
\hline Extent of linear & & & & & 0.0000 & 0.0000 \\
\hline
\end{tabular}




\section{Table 4 - Hedging Strategies}

The table reports the estimates of probit models where the dependent variables are binary variables for the use of a certain hedging strategy. Non-binary variables are winsorized at the $2.5 \%$ on both tails. All regressions include year fixed effects. Figures in parentheses denote heteroskedasticity-robust $\mathrm{t}$-statistics clustered by firm. The symbols $* * *, * *$, and * denotes statistically significance levels at the $1 \%, 5 \%$, and $10 \%$, respectively. Variable definitions are provided in Appendix A.

\begin{tabular}{|c|c|c|c|c|c|c|}
\hline & $\begin{array}{l}\text { Hedger } \\
\text { (I) }\end{array}$ & $\begin{array}{l}\text { Linear } \\
\text { (II) }\end{array}$ & $\begin{array}{c}\text { Lost upside } \\
\text { (III) }\end{array}$ & $\begin{array}{c}\text { Sold Put } \\
\text { (IV) }\end{array}$ & $\begin{array}{l}\text { Bought Put } \\
\text { (V) }\end{array}$ & $\begin{array}{l}\text { Sold Call } \\
(\mathrm{VI})\end{array}$ \\
\hline \multirow[t]{2}{*}{ Constant } & $16.4440 * *$ & $13.4335^{* *}$ & 6.4483 & -2.2249 & -4.3005 & -3.9745 \\
\hline & [7.5213] & [5.5303] & [7.8877] & [8.5060] & [5.8742] & [6.3508] \\
\hline \multirow[t]{2}{*}{$\ln ($ Vega $)$} & $-0.2638^{*}$ & 0.1414 & -0.2768 & 0.0397 & -0.1642 & $-0.2452 *$ \\
\hline & {$[0.1387]$} & {$[0.1168]$} & {$[0.1688]$} & [0.1617] & {$[0.1178]$} & {$[0.1282]$} \\
\hline \multirow[t]{2}{*}{$\ln ($ Delta $)$} & 0.0885 & 0.0588 & -0.0787 & -0.3275 & -0.1293 & 0.0442 \\
\hline & [0.2217] & {$[0.1550]$} & [0.1804] & {$[0.2781]$} & [0.1695] & [0.1709] \\
\hline \multirow[t]{2}{*}{ Ln(Age) } & $-3.6007 *$ & $-3.9401 * * *$ & -1.5768 & -1.1057 & 2.3226 & $2.4327 *$ \\
\hline & [1.9654] & [1.4698] & {$[1.8578]$} & [1.9944] & [1.5469] & [1.4117] \\
\hline \multirow[t]{2}{*}{ Ln(Cash Comp.) } & $-0.9688 * *$ & 0.0356 & $-0.8327 * *$ & 0.1275 & $-0.7768 * * *$ & $-0.8220 * * *$ \\
\hline & {$[0.4404]$} & {$[0.2556]$} & {$[0.3818]$} & {$[0.3718]$} & [0.2709] & {$[0.2602]$} \\
\hline \multirow[t]{2}{*}{ Leverage } & 2.0943 & 0.901 & 1.8082 & 1.2559 & -0.329 & -0.126 \\
\hline & [1.7544] & {$[1.1530]$} & [1.5626] & {$[1.8250]$} & [1.2042] & [0.9883] \\
\hline \multirow[t]{2}{*}{ Dividend } & 0.2541 & -0.1724 & 0.3636 & -0.1043 & -0.1215 & 0.0846 \\
\hline & [0.3659] & [0.3079] & {$[0.4351]$} & {$[0.4140]$} & {$[0.3921]$} & [0.3862] \\
\hline \multirow[t]{2}{*}{ Tobin Q } & $1.4404 * *$ & $1.1341 * *$ & $1.1939^{*}$ & -1.2097 & $-0.9091 *$ & $-0.9546 * *$ \\
\hline & {$[0.6982]$} & {$[0.4770]$} & {$[0.6358]$} & {$[0.7584]$} & {$[0.4663]$} & {$[0.4681]$} \\
\hline \multirow[t]{2}{*}{ Cash reserves } & $-5.7027^{*}$ & -2.6839 & -3.5323 & -6.6723 & $-5.1820 *$ & -2.6777 \\
\hline & [3.2858] & [2.4283] & [3.4422] & [6.5558] & [2.9251] & [2.9885] \\
\hline \multirow[t]{2}{*}{ Duality } & $1.0580 * *$ & $0.4082 *$ & $0.5544^{*}$ & 0.1385 & 0.4506 & 0.2855 \\
\hline & {$[0.4276]$} & {$[0.2128]$} & {$[0.3267]$} & {$[0.3614]$} & {$[0.3431]$} & {$[0.3124]$} \\
\hline \multirow[t]{2}{*}{ Overconfidence } & $-0.5336^{*}$ & -0.3655 & -0.1581 & 0.514 & -0.0212 & 0.004 \\
\hline & {$[0.2917]$} & [0.2594] & [0.2959] & {$[0.4595]$} & {$[0.2104]$} & [0.2267] \\
\hline \multirow[t]{2}{*}{ Ln (Capex/PPE) } & $-1.0079 * *$ & 0.0523 & $-0.9428 * *$ & -0.3376 & -0.4775 & -0.4414 \\
\hline & {$[0.4880]$} & {$[0.3263]$} & {$[0.4342]$} & {$[0.3508]$} & {$[0.3841]$} & {$[0.3647]$} \\
\hline \multirow[t]{2}{*}{$\ln$ (Assets) } & $0.8861 * *$ & -0.3257 & $1.1810^{* * *}$ & $1.0237 * * *$ & $0.8136^{* * *}$ & $1.1162 * * *$ \\
\hline & {$[0.3625]$} & {$[0.2657]$} & {$[0.3626]$} & {$[0.3655]$} & {$[0.2670]$} & {$[0.2826]$} \\
\hline \multirow[t]{2}{*}{$\ln$ (Proved Reserves) } & $-0.5411 * *$ & 0.1868 & $-0.7046 * * *$ & $-0.3880 * *$ & $-0.4635 * * *$ & $-0.7102 * * *$ \\
\hline & {$[0.2233]$} & {$[0.1416]$} & {$[0.2197]$} & {$[0.1725]$} & {$[0.1727]$} & [0.1769] \\
\hline \multirow[t]{2}{*}{ Tenure } & -0.0105 & $0.0509 * *$ & 0.0081 & -0.0147 & -0.0443 & -0.0419 \\
\hline & {$[0.0379]$} & {$[0.0223]$} & {$[0.0360]$} & {$[0.0435]$} & {$[0.0317]$} & {$[0.0280]$} \\
\hline \multirow[t]{2}{*}{ Financial Expertise } & 0.1649 & 0.2418 & 0.7044 & $0.5401 *$ & 0.3379 & 0.406 \\
\hline & {$[0.4480]$} & {$[0.2479]$} & [0.5099] & {$[0.3244]$} & [0.3519] & {$[0.3530]$} \\
\hline Year Fixed Effects & Yes & Yes & Yes & Yes & Yes & Yes \\
\hline Pseudo $\mathrm{R}^{2}$ & 0.3402 & 0.1684 & 0.324 & 0.2877 & 0.3075 & 0.3236 \\
\hline \#Observations & 235 & 235 & 235 & 215 & 235 & 235 \\
\hline
\end{tabular}


Table 5 - Determinants of derivative instrument choice

This table presents multinomial logit regression results of the decision to select one hedging strategies. In Model 1, the four strategies we consider are: no hedging; put only; collar (put \& call); and linear. The base category is no hedging. In Model 2, we consider only collar (base category) and linear. Non-binary variables are winsorized at the $2.5 \%$ on both tails. All regressions include year fixed effects. Figures in parentheses denote heteroskedasticity-robust $\mathrm{t}$-statistics clustered by firm. The symbols ***, **, and * denotes statistically significance levels at the $1 \%, 5 \%$, and $10 \%$, respectively. Variable definitions are provided in Appendix A.

\begin{tabular}{|c|c|c|c|c|}
\hline & $\begin{array}{l}\text { Put Only } \\
\text { (I) }\end{array}$ & $\begin{array}{l}\text { Model } 1 \\
\text { Collar } \\
\text { (II) }\end{array}$ & $\begin{array}{c}\text { Linear } \\
\text { (III) }\end{array}$ & $\begin{array}{l}\text { Model } 2 \\
\text { Linear } \\
\text { (II) }\end{array}$ \\
\hline Constant & $\begin{array}{l}57.7665^{*} \\
{[34.8538]}\end{array}$ & $\begin{array}{c}22.8188 \\
{[19.1544]}\end{array}$ & $\begin{array}{c}50.4056 * * * \\
{[18.9066]}\end{array}$ & $\begin{array}{c}24.8460 * * \\
{[10.7308]}\end{array}$ \\
\hline $\ln ($ Vega $)$ & $\begin{array}{c}0.5043 \\
{[0.4739]}\end{array}$ & $\begin{array}{c}-0.6970 * * \\
{[0.2872]}\end{array}$ & $\begin{array}{l}-0.2933 \\
{[0.2644]}\end{array}$ & $\begin{array}{c}0.3437 * \\
{[0.1934]}\end{array}$ \\
\hline $\ln$ (Delta) & $\begin{array}{c}0.9934 \\
{[0.8101]}\end{array}$ & $\begin{array}{c}0.1937 \\
{[0.4186]}\end{array}$ & $\begin{array}{c}0.3699 \\
{[0.4257]}\end{array}$ & $\begin{array}{c}0.1345 \\
{[0.2670]}\end{array}$ \\
\hline Ln(Age) & $\begin{array}{l}-6.8579 \\
{[8.7942]}\end{array}$ & $\begin{array}{l}-4.0823 \\
{[4.6825]}\end{array}$ & $\begin{array}{c}-11.7035^{* *} \\
{[4.6788]}\end{array}$ & $\begin{array}{c}-7.0052 * * \\
{[2.9719]}\end{array}$ \\
\hline Ln(Cash Comp.) & $\begin{array}{c}-3.5336 * * \\
{[1.7757]}\end{array}$ & $\begin{array}{c}2.4835 * * * \\
{[0.8345]}\end{array}$ & $\begin{array}{c}1.2223 \\
{[0.9619]}\end{array}$ & $\begin{array}{c}-1.2547 * * * \\
{[0.4819]}\end{array}$ \\
\hline Leverage & $\begin{array}{l}-1.0956 \\
{[1.1360]}\end{array}$ & $\begin{array}{c}-2.4741 * * \\
{[1.0362]}\end{array}$ & $\begin{array}{l}-1.9912 * \\
{[1.1548]}\end{array}$ & $\begin{array}{c}0.4748 \\
{[0.4402]}\end{array}$ \\
\hline Dividend & $\begin{array}{c}1.8698 \\
{[5.9405]}\end{array}$ & $\begin{array}{c}2.6488 \\
{[3.8375]}\end{array}$ & $\begin{array}{c}4.1857 \\
{[3.9080]}\end{array}$ & $\begin{array}{c}1.6757 \\
{[2.1558]}\end{array}$ \\
\hline Tobin Q & $\begin{array}{c}-1.09 \\
{[1.3174]}\end{array}$ & $\begin{array}{c}0.888 \\
{[0.8458]}\end{array}$ & $\begin{array}{c}0.2832 \\
{[0.8506]}\end{array}$ & $\begin{array}{c}-0.475 \\
{[0.5035]}\end{array}$ \\
\hline Cash reserves & $\begin{array}{c}1.9365 \\
{[1.7469]}\end{array}$ & $\begin{array}{c}1.9981 \\
{[1.6915]}\end{array}$ & $\begin{array}{c}3.7688 * * \\
{[1.6047]}\end{array}$ & $\begin{array}{l}1.6835 * * \\
{[0.8238]}\end{array}$ \\
\hline Duality & $\begin{array}{c}-51.4420 * * * \\
{[18.1693]}\end{array}$ & $\begin{array}{c}-13.3840 * \\
{[6.8462]}\end{array}$ & $\begin{array}{c}-13.1244 * * \\
{[6.6659]}\end{array}$ & $\begin{array}{l}-1.6965 \\
{[4.0778]}\end{array}$ \\
\hline Overconfidence & $\begin{array}{c}4.2314 * * \\
{[2.0110]}\end{array}$ & $\begin{array}{l}1.9714 * \\
{[1.0191]}\end{array}$ & $\begin{array}{c}2.7183 * * * \\
{[1.0270]}\end{array}$ & $\begin{array}{l}0.7435^{*} \\
{[0.4471]}\end{array}$ \\
\hline Ln (Capex/PPE) & $\begin{array}{c}-4.0763 * * \\
{[1.6299]}\end{array}$ & $\begin{array}{l}-0.9265 \\
{[0.5974]}\end{array}$ & $\begin{array}{c}-1.5135 * * \\
{[0.6839]}\end{array}$ & $\begin{array}{l}-0.5808 \\
{[0.5005]}\end{array}$ \\
\hline $\ln$ (Assets) & $\begin{array}{l}-0.6673 \\
{[1.3098]}\end{array}$ & $\begin{array}{c}-1.9296^{* *} \\
{[0.9736]}\end{array}$ & $\begin{array}{l}-1.5182 \\
{[1.1219]}\end{array}$ & $\begin{array}{c}0.6151 \\
{[0.6309]}\end{array}$ \\
\hline $\ln$ (Proved Reserves) & $\begin{array}{c}0.4081 \\
{[1.0038]}\end{array}$ & $\begin{array}{c}-1.3975^{* *} \\
{[0.5918]}\end{array}$ & $\begin{array}{c}-0.764 \\
{[0.5767]}\end{array}$ & $\begin{array}{c}0.6713 * * \\
{[0.3067]}\end{array}$ \\
\hline Tenure & $\begin{array}{c}0.0647 \\
{[0.1040]}\end{array}$ & $\begin{array}{l}-0.0485 \\
{[0.0740]}\end{array}$ & $\begin{array}{c}0.0355 \\
{[0.0749]}\end{array}$ & $\begin{array}{l}0.0728 * \\
{[0.0391]}\end{array}$ \\
\hline Financial Expertise & $\begin{array}{c}-19.8052 * * * \\
{[3.4416]}\end{array}$ & $\begin{array}{c}0.2202 \\
{[0.9659]}\end{array}$ & $\begin{array}{c}0.2573 \\
{[0.9675]}\end{array}$ & $\begin{array}{c}0.0805 \\
{[0.4110]}\end{array}$ \\
\hline $\begin{array}{l}\text { Year Fixed Effects } \\
\text { Pseudo } \mathrm{R}^{2} \\
\text { \#Observations }\end{array}$ & Yes & $\begin{array}{c}\text { Yes } \\
0.3359 \\
232\end{array}$ & Yes & $\begin{array}{c}\text { Yes } \\
0.2242 \\
194\end{array}$ \\
\hline
\end{tabular}




\section{Table 6 - The extent of using hedging strategies}

This table presents estimates of random effects tobit model regressions, evaluating the determinants of the extent of choosing different options strategies. The dependent variables are: Extent of Insurance (I), Extent of Selling calls (II); Extent of Collar (III); Extent of Linear (IV). Non-binary variables are winsorized at the $2.5 \%$ on both tails. All regressions include year fixed effects. Figures in parentheses denote heteroskedasticity-robust $\mathrm{t}$-statistics clustered by firm. The symbols $* * *, * *$, and $*$ denotes statistically significance levels at the $1 \%, 5 \%$, and $10 \%$, respectively. Variable definitions are provided in Appendix A.

\begin{tabular}{|c|c|c|c|c|}
\hline Extent of: & $\begin{array}{l}\text { Insurance } \\
\text { (I) }\end{array}$ & $\begin{array}{l}\text { Selling Calls } \\
\text { (II) }\end{array}$ & $\begin{array}{l}\text { Collar } \\
\text { (III) }\end{array}$ & $\begin{array}{l}\text { Linear } \\
\text { (IV) }\end{array}$ \\
\hline Constant & $\begin{array}{c}-6.0925 * * \\
{[2.9035]}\end{array}$ & $\begin{array}{c}-6.0236 * * \\
{[2.6979]}\end{array}$ & $\begin{array}{c}-6.4685 * * \\
{[2.8968]}\end{array}$ & $\begin{array}{l}6.6173 * * \\
{[2.7282]}\end{array}$ \\
\hline $\ln ($ Vega $)$ & $\begin{array}{c}-0.0397 \\
{[0.0422]}\end{array}$ & $\begin{array}{c}-0.0404 \\
{[0.0420]}\end{array}$ & $\begin{array}{l}-0.0233 \\
{[0.0440]}\end{array}$ & $\begin{array}{c}0.0539 \\
{[0.0407]}\end{array}$ \\
\hline $\ln ($ Delta $)$ & $\begin{array}{c}0.0126 \\
{[0.0696]}\end{array}$ & $\begin{array}{c}0.0481 \\
{[0.0671]}\end{array}$ & $\begin{array}{c}0.0121 \\
{[0.0704]}\end{array}$ & $\begin{array}{l}-0.0485 \\
{[0.0670]}\end{array}$ \\
\hline Ln(Age) & $\begin{array}{l}1.7022 * * \\
{[0.7446]}\end{array}$ & $\begin{array}{c}1.8495 * * * \\
{[0.6930]}\end{array}$ & $\begin{array}{l}1.8491 * * \\
{[0.7419]}\end{array}$ & $\begin{array}{c}-1.6971 * * \\
{[0.7018]}\end{array}$ \\
\hline Ln(Cash Comp.) & $\begin{array}{c}0.0811 \\
{[0.1085]}\end{array}$ & $\begin{array}{c}0.0987 \\
{[0.1039]}\end{array}$ & $\begin{array}{c}0.101 \\
{[0.1097]}\end{array}$ & $\begin{array}{l}-0.0739 \\
{[0.1036]}\end{array}$ \\
\hline Leverage & $\begin{array}{l}-0.0155 \\
{[0.0977]}\end{array}$ & $\begin{array}{l}-0.0377 \\
{[0.0958]}\end{array}$ & $\begin{array}{l}-0.0231 \\
{[0.1002]}\end{array}$ & $\begin{array}{c}0.0273 \\
{[0.0940]}\end{array}$ \\
\hline Dividend & $\begin{array}{c}0.1187 \\
{[0.4660]}\end{array}$ & $\begin{array}{c}0.125 \\
{[0.4544]}\end{array}$ & $\begin{array}{l}-0.0401 \\
{[0.4759]}\end{array}$ & $\begin{array}{c}-0.2828 \\
{[0.4484]}\end{array}$ \\
\hline Tobin Q & $\begin{array}{c}0.3126^{* *} \\
{[0.1371]}\end{array}$ & $\begin{array}{l}0.2926^{* *} \\
{[0.1317]}\end{array}$ & $\begin{array}{c}0.2995 * * \\
{[0.1389]}\end{array}$ & $\begin{array}{c}-0.3076^{* *} \\
{[0.1310]}\end{array}$ \\
\hline Cash reserves & $\begin{array}{c}-0.1165 \\
{[0.1560]}\end{array}$ & $\begin{array}{c}-0.204 \\
{[0.1542]}\end{array}$ & $\begin{array}{l}-0.1032 \\
{[0.1601]}\end{array}$ & $\begin{array}{c}0.2153 \\
{[0.1509]}\end{array}$ \\
\hline Duality & $\begin{array}{c}0.9799 \\
{[1.1235]}\end{array}$ & $\begin{array}{c}0.9134 \\
{[1.1139]}\end{array}$ & $\begin{array}{c}0.8364 \\
{[1.1536]}\end{array}$ & $\begin{array}{l}-1.0334 \\
{[1.0922]}\end{array}$ \\
\hline Overconfidence & $\begin{array}{c}-0.019 \\
{[0.1101]}\end{array}$ & $\begin{array}{l}-0.0098 \\
{[0.1068]}\end{array}$ & $\begin{array}{l}-0.0096 \\
{[0.1118]}\end{array}$ & $\begin{array}{c}0.0172 \\
{[0.1059]}\end{array}$ \\
\hline Ln (Capex/PPE) & $\begin{array}{c}-0.0018 \\
{[0.0954]}\end{array}$ & $\begin{array}{c}0.0358 \\
{[0.0961]}\end{array}$ & $\begin{array}{l}-0.0086 \\
{[0.0983]}\end{array}$ & $\begin{array}{c}-0.0436 \\
{[0.0934]}\end{array}$ \\
\hline $\ln$ (Assets) & $\begin{array}{c}-0.0793 \\
{[0.1151]}\end{array}$ & $\begin{array}{l}-0.1098 \\
{[0.1145]}\end{array}$ & $\begin{array}{l}-0.1159 \\
{[0.1187]}\end{array}$ & $\begin{array}{c}0.0735 \\
{[0.1115]}\end{array}$ \\
\hline $\ln$ (Proved Res.) & $\begin{array}{l}-0.0668 \\
{[0.0657]}\end{array}$ & $\begin{array}{l}-0.0987 \\
{[0.0610]}\end{array}$ & $\begin{array}{l}-0.0925 \\
{[0.0655]}\end{array}$ & $\begin{array}{c}0.0722 \\
{[0.0619]}\end{array}$ \\
\hline Tenure & $\begin{array}{c}-0.0354 * * \\
{[0.0138]}\end{array}$ & $\begin{array}{c}-0.0395^{* * *} \\
{[0.0128]}\end{array}$ & $\begin{array}{c}-0.0377 * * * \\
{[0.0138]}\end{array}$ & $\begin{array}{c}0.0378 * * * \\
{[0.0129]}\end{array}$ \\
\hline Financial Expertise & $\begin{array}{c}-0.1432 \\
{[0.1171]}\end{array}$ & $\begin{array}{c}-0.1784 \\
{[0.1114]}\end{array}$ & $\begin{array}{c}-0.1675 \\
{[0.1177]}\end{array}$ & $\begin{array}{c}0.1519 \\
{[0.1118]}\end{array}$ \\
\hline Random Firm Effects & Yes & Yes & Yes & Yes \\
\hline Year Fixed Effects & Yes & Yes & Yes & Yes \\
\hline \#Observations & 197 & 197 & 197 & 197 \\
\hline
\end{tabular}




\section{Table 7 - Age and Corporate investments}

This table presents estimates of pooled OLS regressions (Columns I to III) and pooled logit models (Column IV), evaluating the real corporate investments. The dependent variables are: Exploration Expenses (I), Capex (II); and Acquisition Size (III); Acquisition dummy (IV). Non-binary variables are winsorized at the $2.5 \%$ on both tails. All regressions include year fixed effects. Figures in parentheses denote heteroskedasticity-robust t-statistics clustered by firm. The symbols $* * *, * *$, and * denotes statistically significance levels at the $1 \%$, $5 \%$, and $10 \%$, respectively. Variable definitions are provided in Appendix A.

\begin{tabular}{|c|c|c|c|c|}
\hline & $\begin{array}{c}\text { Exploration } \\
\text { Expenses } \\
\text { (I) }\end{array}$ & $\begin{array}{l}\text { Capex } \\
\text { (II) }\end{array}$ & $\begin{array}{l}\text { Acquisition Size } \\
\text { (III) }\end{array}$ & $\begin{array}{c}\text { Acquisition } \\
\text { Dummy } \\
\text { (IV) }\end{array}$ \\
\hline Constant & $\begin{array}{l}0.1264 * \\
{[0.0707]}\end{array}$ & $\begin{array}{c}0.7474 \\
{[1.8457]}\end{array}$ & $\begin{array}{c}-0.9757 \\
{[1.2922]}\end{array}$ & $\begin{array}{c}-17.9807^{* *} \\
{[9.1389]}\end{array}$ \\
\hline $\ln ($ Vega $)$ & $\begin{array}{c}0.0001 \\
{[0.0017]}\end{array}$ & $\begin{array}{c}0.0051 \\
{[0.0250]}\end{array}$ & $\begin{array}{c}0.0025 \\
{[0.0292]}\end{array}$ & $\begin{array}{c}-0.0738 \\
{[0.1729]}\end{array}$ \\
\hline $\ln ($ Delta $)$ & $\begin{array}{c}-0.0024 \\
{[0.0029]}\end{array}$ & $\begin{array}{c}0.0507 \\
{[0.0410]}\end{array}$ & $\begin{array}{c}0.0555 \\
{[0.0370]}\end{array}$ & $\begin{array}{l}-0.0931 \\
{[0.1931]}\end{array}$ \\
\hline Ln(Age) & $\begin{array}{c}-0.005 \\
{[0.0191]}\end{array}$ & $\begin{array}{c}-0.314 \\
{[0.5086]}\end{array}$ & $\begin{array}{c}0.164 \\
{[0.3000]}\end{array}$ & $\begin{array}{c}2.522 \\
{[2.1938]}\end{array}$ \\
\hline Ln(Cash Comp.) & $\begin{array}{c}-0.0079 * * * \\
{[0.0026]}\end{array}$ & $\begin{array}{c}0.0774 \\
{[0.0687]}\end{array}$ & $\begin{array}{c}0.0941 \\
{[0.0690]}\end{array}$ & $\begin{array}{c}0.6485 \\
{[0.4738]}\end{array}$ \\
\hline Leverage & $\begin{array}{l}-0.0154 \\
{[0.0154]}\end{array}$ & $\begin{array}{c}-0.0184 \\
{[0.3035]}\end{array}$ & $\begin{array}{l}0.6190 * * \\
{[0.2649]}\end{array}$ & $\begin{array}{c}2.848 \\
{[2.1549]}\end{array}$ \\
\hline Dividend & $\begin{array}{l}-0.0029 \\
{[0.0054]}\end{array}$ & $\begin{array}{c}-0.1172 \\
{[0.0757]}\end{array}$ & $\begin{array}{c}-0.1783 * * \\
{[0.0843]}\end{array}$ & $\begin{array}{l}-0.6185 \\
{[0.5675]}\end{array}$ \\
\hline Tobin Q & $\begin{array}{c}0.001 \\
{[0.0043]}\end{array}$ & $\begin{array}{c}0.0895 \\
{[0.0969]}\end{array}$ & $\begin{array}{c}0.1808 \\
{[0.1238]}\end{array}$ & $\begin{array}{c}0.4069 \\
{[0.6663]}\end{array}$ \\
\hline Cash reserves & $\begin{array}{c}0.0309 \\
{[0.0516]}\end{array}$ & $\begin{array}{c}0.0505 \\
{[0.7509]}\end{array}$ & $\begin{array}{c}-1.4650 * * \\
{[0.6883]}\end{array}$ & $\begin{array}{l}-4.5394 \\
{[4.7884]}\end{array}$ \\
\hline Duality & $\begin{array}{c}-0.0023 \\
{[0.0045]}\end{array}$ & $\begin{array}{c}-0.0797 \\
{[0.0673]}\end{array}$ & $\begin{array}{l}-0.0696 \\
{[0.0712]}\end{array}$ & $\begin{array}{l}-0.4267 \\
{[0.3814]}\end{array}$ \\
\hline Overconfidence & $\begin{array}{c}0.0009 \\
{[0.0036]}\end{array}$ & $\begin{array}{c}-0.0438 \\
{[0.0642]}\end{array}$ & $\begin{array}{c}0.0303 \\
{[0.0778]}\end{array}$ & $\begin{array}{c}0.4147 \\
{[0.4203]}\end{array}$ \\
\hline Ln (Capex/PPE) & $\begin{array}{c}0.0081 \\
{[0.0058]}\end{array}$ & & $\begin{array}{c}0.0461 \\
{[0.0738]}\end{array}$ & $\begin{array}{c}0.0213 \\
{[0.4508]}\end{array}$ \\
\hline $\ln$ (Assets) & $\begin{array}{c}-0.0024 \\
{[0.0042]}\end{array}$ & $\begin{array}{c}-0.0948 \\
{[0.0908]}\end{array}$ & $\begin{array}{c}-0.077 \\
{[0.0630]}\end{array}$ & $\begin{array}{c}-0.183 \\
{[0.3556]}\end{array}$ \\
\hline $\ln$ (Proved Reserves) & $\begin{array}{c}0.0019 \\
{[0.0028]}\end{array}$ & $\begin{array}{c}-0.0521 \\
{[0.0494]}\end{array}$ & $\begin{array}{c}0.0234 \\
{[0.0406]}\end{array}$ & $\begin{array}{c}0.179 \\
{[0.2427]}\end{array}$ \\
\hline Tenure & $\begin{array}{c}0.0004 \\
{[0.0004]}\end{array}$ & $\begin{array}{c}0.0038 \\
{[0.0075]}\end{array}$ & $\begin{array}{l}-0.0115^{*} \\
{[0.0061]}\end{array}$ & $\begin{array}{c}-0.0182 \\
{[0.0387]}\end{array}$ \\
\hline Financial Expertise & $\begin{array}{c}-0.0042 \\
{[0.0041]}\end{array}$ & $\begin{array}{c}0.0666 \\
{[0.0674]}\end{array}$ & $\begin{array}{l}-0.0429 \\
{[0.0718]}\end{array}$ & $\begin{array}{l}-0.0357 \\
{[0.4030]}\end{array}$ \\
\hline $\begin{array}{l}\text { Year Fixed Effects } \\
\text { AR2/Pseudo R2 } \\
\text { \#Observations }\end{array}$ & $\begin{array}{c}\text { Yes } \\
0.3738 \\
151\end{array}$ & $\begin{array}{c}\text { Yes } \\
0.2454 \\
237\end{array}$ & $\begin{array}{c}\text { Yes } \\
0.0552 \\
236\end{array}$ & $\begin{array}{c}\text { Yes } \\
0.2392 \\
189\end{array}$ \\
\hline
\end{tabular}


Table 8 - Hedging Strategies and the rising oil price

The table reports the estimates of linear probability models (OLS) where the dependent variables are binary variables for the use of a certain hedging strategy. Non-binary variables are winsorized at the $2.5 \%$ on both tails. All regressions include year fixed effects. Figures in parentheses denote heteroskedasticity-robust tstatistics clustered by firm. The symbols $* * *, * *$, and * denotes statistically significance levels at the $1 \%$, $5 \%$, and $10 \%$, respectively. Variable definitions are provided in Appendix A.

\begin{tabular}{|c|c|c|}
\hline & $\begin{array}{l}\text { Hedger } \\
\text { (I) }\end{array}$ & $\begin{array}{c}\text { Linear } \\
\text { (II) }\end{array}$ \\
\hline Constant & $\begin{array}{c}6.5822 * * * \\
{[2.3939]}\end{array}$ & $\begin{array}{c}9.4176^{* * * *} \\
{[1.8761]}\end{array}$ \\
\hline $\ln$ (Vega) & $\begin{array}{l}-0.0552 \\
{[0.0373]}\end{array}$ & $\begin{array}{c}0.0156 \\
{[0.0557]}\end{array}$ \\
\hline $\ln ($ Delta) & $\begin{array}{c}0.0614 \\
{[0.0430]}\end{array}$ & $\begin{array}{c}0.0910 * \\
{[0.0538]}\end{array}$ \\
\hline Ln(Age) & $\begin{array}{c}-1.4235^{* *} \\
{[0.6251]}\end{array}$ & $\begin{array}{c}-2.3963 * * * \\
{[0.4900]}\end{array}$ \\
\hline $\ln ($ Vega)*Post 2004 & $\begin{array}{c}0.0314 \\
{[0.0338]}\end{array}$ & $\begin{array}{c}0.0199 \\
{[0.0592]}\end{array}$ \\
\hline $\ln ($ Delta) *Post 2004 & $\begin{array}{c}-0.0957 * * \\
{[0.0406]}\end{array}$ & $\begin{array}{l}-0.1038^{*} \\
{[0.0561]}\end{array}$ \\
\hline $\operatorname{Ln}($ Age $)) *$ Post 2004 & $\begin{array}{c}1.8548 * * * \\
{[0.6741]}\end{array}$ & $\begin{array}{c}2.3114 * * * * \\
{[0.6707]}\end{array}$ \\
\hline Ln(Cash Comp.) & $\begin{array}{c}-0.1099 * * \\
{[0.0532]}\end{array}$ & $\begin{array}{c}0.0093 \\
{[0.0798]}\end{array}$ \\
\hline Leverage & $\begin{array}{c}0.1996 \\
{[0.2176]}\end{array}$ & $\begin{array}{c}0.4974 \\
{[0.4021]}\end{array}$ \\
\hline Dividend & $\begin{array}{c}0.0145 \\
{[0.0544]}\end{array}$ & $\begin{array}{c}-0.058 \\
{[0.1056]}\end{array}$ \\
\hline Tobin Q & $\begin{array}{c}0.0805 \\
{[0.0705]}\end{array}$ & $\begin{array}{l}0.2995^{*} \\
{[0.1632]}\end{array}$ \\
\hline Cash reserves & $\begin{array}{c}-1.1914 \\
{[0.7331]}\end{array}$ & $\begin{array}{c}-0.517 \\
{[0.7151]}\end{array}$ \\
\hline Duality & $\begin{array}{l}0.1207 * * \\
{[0.0532]}\end{array}$ & $\begin{array}{l}0.1438^{*} \\
{[0.0725]}\end{array}$ \\
\hline Overconfidence & $\begin{array}{l}-0.0800^{*} \\
{[0.0469]}\end{array}$ & $\begin{array}{c}-0.1005 \\
{[0.0822]}\end{array}$ \\
\hline Ln (Capex/PPE) & $\begin{array}{c}-0.0645 \\
{[0.0761]}\end{array}$ & $\begin{array}{c}0.0614 \\
{[0.1047]}\end{array}$ \\
\hline $\ln$ (Assets) & $\begin{array}{c}0.1113 * * \\
{[0.0512]}\end{array}$ & $\begin{array}{c}-0.0749 \\
{[0.0798]}\end{array}$ \\
\hline ln(Proved Reserves) & $\begin{array}{l}-0.0490^{*} \\
{[0.0271]}\end{array}$ & $\begin{array}{c}0.0444 \\
{[0.0437]}\end{array}$ \\
\hline Tenure & $\begin{array}{c}0.0034 \\
{[0.0076]}\end{array}$ & $\begin{array}{l}0.0168 * * \\
{[0.0063]}\end{array}$ \\
\hline Financial Expertise & $\begin{array}{c}0.0468 \\
{[0.0694]}\end{array}$ & $\begin{array}{c}0.0955 \\
{[0.0911]}\end{array}$ \\
\hline $\begin{array}{l}\text { Year Fixed Effects } \\
\text { Adj. } \mathrm{R}^{2} \\
\text { \#Observations }\end{array}$ & $\begin{array}{c}\text { Yes } \\
0.2038 \\
235\end{array}$ & $\begin{array}{c}\text { Yes } \\
0.1628 \\
235\end{array}$ \\
\hline
\end{tabular}




\section{Table 9-IV approach}

The table presents the results of an instrumental variable analysis, $\operatorname{Ln}($ Age $)$ is instrumented by the log of CPI at birth, which is the consumer price index in the year the CEO was born. Panel A reports the estimates of the second stage of IV probit models where the dependent variables are binary variables for the use of a certain hedging strategy. Panel B presents IV multinomial logit regression results of the decision to select one hedging strategies. The four strategies we consider are: no hedging; put only; collar (put \& call); and linear. The base category is no hedging. Ln(Age) is instrumented by the log of CPI at birth, which is the consumer price index in the year the CEO was born. The first-stage regression regress $\ln (\mathrm{Age})$ on $\ln (\mathrm{CPI}$ at birth), the instrument, and the control variables listed in the table. Panel $\mathrm{C}$ presents estimates of random effects tobit model regressions, evaluating the determinants of the extent of choosing different options strategies. The dependent variables are: Extent of Insurance (I), Extent of Selling calls (II); Extent of Collar (III); Extent of Linear (IV). Ln(Age) is instrumented by the log of CPI at birth, which is the consumer price index in the year the CEO was born. The first-stage regression regress $\ln ($ Age) on $\ln (\mathrm{CPI}$ at birth), the instrument, and the control variables listed in the table. Panel D presents estimates of IV OLS regressions, evaluating the real corporate investments. The dependent variables are: Exploration Expenses (I), Capex (II); and Acquisition Size (III). Non-binary variables are winsorized at the $2.5 \%$ on both tails. All regressions include year fixed effects. Figures in parentheses denote heteroskedasticity-robust $\mathrm{t}$-statistics clustered by firm. The symbols ***, **, and * denotes statistically significance levels at the $1 \%, 5 \%$, and 10\%, respectively. Variable definitions are provided in Appendix A.

Panel A: Use of Hedging Strategy

\begin{tabular}{|c|c|c|c|c|c|c|}
\hline & $\begin{array}{l}\text { Hedger } \\
\text { (I) }\end{array}$ & $\begin{array}{c}\text { Linear } \\
\text { (II) }\end{array}$ & $\begin{array}{l}\text { Lost upside } \\
\text { (III) }\end{array}$ & $\begin{array}{l}\text { Sold Put } \\
\text { (IV) }\end{array}$ & $\begin{array}{c}\text { Bought Put } \\
\text { (V) }\end{array}$ & $\begin{array}{c}\text { Sold Call } \\
(\mathrm{VI})\end{array}$ \\
\hline $\ln ($ Vega $)$ & $\begin{array}{c}-0.2361 * \\
{[0.1345]}\end{array}$ & $\begin{array}{c}0.1608 \\
{[0.1178]}\end{array}$ & $\begin{array}{c}-0.2455 \\
{[0.1675]}\end{array}$ & $\begin{array}{c}0.0462 \\
{[0.1567]}\end{array}$ & $\begin{array}{c}-0.1687 \\
{[0.1206]}\end{array}$ & $\begin{array}{c}-0.2470 * \\
{[0.1290]}\end{array}$ \\
\hline $\ln ($ Delta $)$ & $\begin{array}{c}0.0392 \\
{[0.2140]}\end{array}$ & $\begin{array}{c}0.0223 \\
{[0.1526]}\end{array}$ & $\begin{array}{c}-0.142 \\
{[0.1847]}\end{array}$ & $\begin{array}{l}-0.3331 \\
{[0.2811]}\end{array}$ & $\begin{array}{l}-0.1191 \\
{[0.1673]}\end{array}$ & $\begin{array}{c}0.0477 \\
{[0.1745]}\end{array}$ \\
\hline Instr. Ln(Age) & $\begin{array}{c}-4.5074 * * \\
{[2.1317]}\end{array}$ & $\begin{array}{c}-5.0051 * * * \\
{[1.7353]}\end{array}$ & $\begin{array}{l}-2.5332 \\
{[2.0422]}\end{array}$ & $\begin{array}{l}-1.4389 \\
{[2.0848]}\end{array}$ & $\begin{array}{c}2.5112 \\
{[1.7925]}\end{array}$ & $\begin{array}{c}2.4889 \\
{[1.5679]}\end{array}$ \\
\hline $\begin{array}{l}\text { Controls } \\
\text { Year Fixed Effects } \\
\text { \#Observations }\end{array}$ & $\begin{array}{l}\text { Yes } \\
\text { Yes } \\
235\end{array}$ & $\begin{array}{l}\text { Yes } \\
\text { Yes } \\
235\end{array}$ & $\begin{array}{l}\text { Yes } \\
\text { Yes } \\
235\end{array}$ & $\begin{array}{l}\text { Yes } \\
\text { Yes } \\
215\end{array}$ & $\begin{array}{l}\text { Yes } \\
\text { Yes } \\
235\end{array}$ & $\begin{array}{l}\text { Yes } \\
\text { Yes } \\
235\end{array}$ \\
\hline
\end{tabular}

Panel B: Multinomial Logit

\begin{tabular}{|c|c|c|c|c|c|c|}
\hline & $\begin{array}{l}\text { Put Only } \\
\text { (I) }\end{array}$ & $\begin{array}{c}\text { Collar } \\
\text { (II) }\end{array}$ & $\begin{array}{l}\text { Linear } \\
\text { (III) }\end{array}$ & $\begin{array}{l}\text { Put Only } \\
\text { (I) }\end{array}$ & $\begin{array}{c}\text { Collar } \\
\text { (II) }\end{array}$ & $\begin{array}{c}\text { Linear } \\
\text { (III) }\end{array}$ \\
\hline $\ln ($ Vega $)$ & $\begin{array}{c}0.5471 \\
{[0.5508]}\end{array}$ & $\begin{array}{c}-0.6586 * * \\
{[0.2722]}\end{array}$ & $\begin{array}{c}-0.2135 \\
{[0.2406]}\end{array}$ & $\begin{array}{c}0.5427 \\
{[0.6214]}\end{array}$ & $\begin{array}{c}-0.6580 * * \\
{[0.2759]}\end{array}$ & $\begin{array}{c}-0.2196 \\
{[0.2481]}\end{array}$ \\
\hline $\ln$ (Delta) & $\begin{array}{c}0.9551 \\
{[0.8097]}\end{array}$ & $\begin{array}{c}0.1577 \\
{[0.4718]}\end{array}$ & $\begin{array}{c}0.3024 \\
{[0.4693]}\end{array}$ & $\begin{array}{c}0.9391 \\
{[0.7433]}\end{array}$ & $\begin{array}{c}0.1438 \\
{[0.4493]}\end{array}$ & $\begin{array}{c}0.2824 \\
{[0.4489]}\end{array}$ \\
\hline Instr. Ln(Age) & $\begin{array}{c}-7.8262 \\
{[14.9316]}\end{array}$ & $\begin{array}{c}-4.8965 \\
{[5.5041]}\end{array}$ & $\begin{array}{c}-14.4396 * * \\
{[5.8927]}\end{array}$ & & & \\
\hline $\operatorname{Ln}($ Age $)$ & & & & $\begin{array}{c}-7.9867 \\
{[17.8000]}\end{array}$ & $\begin{array}{c}-5.1011 \\
{[5.4538]}\end{array}$ & $\begin{array}{c}-14.5310 * * \\
{[5.9142]}\end{array}$ \\
\hline Residuals & & & & $\begin{array}{c}5.3522 \\
{[26.4204]}\end{array}$ & $\begin{array}{c}3.933 \\
{[8.2617]}\end{array}$ & $\begin{array}{c}11.079 \\
{[10.4526]}\end{array}$ \\
\hline Controls & Yes & Yes & Yes & Yes & Yes & Yes \\
\hline Year Fixed Effects & Yes & Yes & Yes & Yes & Yes & Yes \\
\hline Pseudo $R^{2}$ & & 0.3396 & & & 0.3401 & \\
\hline \#Observations & & 232 & & & 232 & \\
\hline
\end{tabular}


Panel C: Extent of Options Strategies

\begin{tabular}{lcccc}
\hline Extent of: & $\begin{array}{c}\text { Insurance } \\
\text { (I) }\end{array}$ & $\begin{array}{c}\text { Selling Calls } \\
(\text { II) }\end{array}$ & $\begin{array}{c}\text { Collar } \\
\text { (III) }\end{array}$ & $\begin{array}{c}\text { Linear } \\
\text { (IV) }\end{array}$ \\
\hline & & & & \\
$\ln ($ Vega) & -0.0383 & -0.0382 & -0.0202 & 0.0534 \\
& {$[0.0421]$} & {$[0.0419]$} & {$[0.0439]$} & {$[0.0406]$} \\
$\ln ($ Delta) & 0.0391 & 0.081 & 0.0438 & -0.0746 \\
& {$[0.0627]$} & {$[0.0608]$} & {$[0.0638]$} & {$[0.0602]$} \\
Ln(Age) & $2.0579^{* *}$ & $2.3080^{* * *}$ & $2.2089^{* * *}$ & $-2.1404 * * *$ \\
& {$[0.8221]$} & {$[0.7944]$} & {$[0.8314]$} & {$[0.7898]$} \\
Controls & Yes & Yes & Yes & Yes \\
Random Firm Effects & Yes & Yes & Yes & Yes \\
Year Fixed Effects & Yes & Yes & Yes & Yes \\
\#Observations & 197 & 197 & 197 & 197 \\
& & & & \\
\hline
\end{tabular}

Panel D: Real Investments

\begin{tabular}{lccc}
\hline & $\begin{array}{c}\text { Exploration Expenses } \\
(\mathrm{I})\end{array}$ & $\begin{array}{c}\text { Capex } \\
\text { (II) }\end{array}$ & $\begin{array}{c}\text { Acquisition Size } \\
\text { (III) }\end{array}$ \\
\hline & & & \\
$\ln$ (Vega) & 0.0000 & 0.0102 & 0.0049 \\
& {$[0.0015]$} & {$[0.0239]$} & {$[0.0276]$} \\
$\ln$ (Delta) & -0.0023 & 0.0379 & 0.0497 \\
& {$[0.0026]$} & {$[0.0382]$} & {$[0.0347]$} \\
Ln(Age) & -0.0022 & -0.6228 & 0.0245 \\
& {$[0.0172]$} & {$[0.5103]$} & {$[0.2735]$} \\
Year Fixed Effects & & & \\
AR2 & Yes & Yes & 0.0552 \\
\#Observations & 0.3738 & 0.2454 & 236 \\
& 151 & 237 & \\
\hline
\end{tabular}




\section{Table 10 - Long-tenured CEOs}

In Panel A, the table reports the estimates of probit models where the dependent variables are binary variables for the use of a certain hedging strategy. Only observations where CEO tenure is larger than 3 years are included in the sample. Panel B presents estimates of random effects tobit model regressions, evaluating the determinants of the extent of choosing different options strategies. The dependent variables are: Extent of Insurance (I), Extent of Selling calls (II); Extent of Collar (III); Extent of Linear (IV).Non-binary variables are winsorized at the $2.5 \%$ on both tails. All regressions include year fixed effects. Figures in parentheses denote heteroskedasticity-robust t-statistics clustered by firm. The symbols ***, **, and * denotes statistically significance levels at the $1 \%, 5 \%$, and $10 \%$, respectively. Variable definitions are provided in Appendix A.

Panel A

\begin{tabular}{|c|c|c|c|c|c|c|}
\hline & $\begin{array}{c}\text { Hedger } \\
\text { (I) }\end{array}$ & $\begin{array}{c}\text { Linear } \\
\text { (II) }\end{array}$ & $\begin{array}{c}\text { Lost upside } \\
\text { (III) }\end{array}$ & $\begin{array}{c}\text { Sold Put } \\
\text { (IV) }\end{array}$ & $\begin{array}{c}\text { Bought Put } \\
\text { (V) }\end{array}$ & $\begin{array}{c}\text { Sold Call } \\
(\mathrm{VI})\end{array}$ \\
\hline $\ln ($ Vega $)$ & $\begin{array}{c}-0.2383 \\
{[0.1460]}\end{array}$ & $\begin{array}{c}0.1124 \\
{[0.1433]}\end{array}$ & $\begin{array}{c}-0.2288 \\
{[0.1654]}\end{array}$ & $\begin{array}{c}-0.1649 \\
{[0.1906]}\end{array}$ & $\begin{array}{c}-0.2213 * \\
{[0.1331]}\end{array}$ & $\begin{array}{c}-0.2 \\
{[0.1475]}\end{array}$ \\
\hline $\ln ($ Delta) & $\begin{array}{c}-0.0827 \\
{[0.3006]}\end{array}$ & $\begin{array}{c}0.0951 \\
{[0.1642]}\end{array}$ & $\begin{array}{c}-0.3465 \\
{[0.2630]}\end{array}$ & $\begin{array}{c}-0.3481 \\
{[0.2612]}\end{array}$ & $\begin{array}{c}-0.1832 \\
{[0.1551]}\end{array}$ & $\begin{array}{c}-0.0499 \\
{[0.1740]}\end{array}$ \\
\hline Ln(Age) & $\begin{array}{l}-4.3058^{*} \\
{[2.3372]}\end{array}$ & $\begin{array}{c}-6.4788 * * * \\
{[1.9387]}\end{array}$ & $\begin{array}{l}-3.9555^{*} \\
{[2.1835]}\end{array}$ & $\begin{array}{c}3.0475 \\
{[2.4528]}\end{array}$ & $\begin{array}{c}5.0491 * * * * \\
{[1.6524]}\end{array}$ & $\begin{array}{l}3.5798 * * \\
{[1.8181]}\end{array}$ \\
\hline Controls & Yes & Yes & Yes & Yes & Yes & Yes \\
\hline Year Fixed Effects & Yes & Yes & Yes & Yes & Yes & Yes \\
\hline Pseudo $\mathrm{R}^{2}$ & 0.267 & 0.2416 & 0.301 & 0.3368 & 0.3063 & 0.3034 \\
\hline \#Observations & 150 & 166 & 166 & 153 & 166 & 166 \\
\hline
\end{tabular}

Panel B

\begin{tabular}{lcccc}
\hline Extent of: & $\begin{array}{c}\text { Insurance } \\
\text { (I) }\end{array}$ & $\begin{array}{c}\text { Selling Calls } \\
\text { (II) }\end{array}$ & $\begin{array}{c}\text { Collar } \\
\text { (III) }\end{array}$ & $\begin{array}{c}\text { Linear } \\
\text { (IV) }\end{array}$ \\
\hline & & & & \\
$\ln ($ Vega) & -0.0298 & -0.0057 & 0.0079 & 0.0384 \\
& {$[0.0522]$} & {$[0.0505]$} & {$[0.0544]$} & {$[0.0489]$} \\
$\ln ($ Delta) & -0.0293 & 0.0321 & -0.0063 & -0.009 \\
& {$[0.0805]$} & {$[0.0768]$} & {$[0.0832]$} & {$[0.0746]$} \\
Ln(Age) & $2.1741^{* *}$ & $2.0461^{* *}$ & $2.0333^{*}$ & $-2.1812^{* *}$ \\
& {$[1.0116]$} & {$[0.9435]$} & {$[1.0555]$} & {$[0.9142]$} \\
Controls & & & & \\
Random Firm Effects & Yes & Yes & Yes & Yes \\
Year Fixed Effects & Yes & Yes & Yes & Yes \\
\#Observations & 197 & 197 & 197 & 197 \\
& & & & \\
\hline
\end{tabular}




\section{Appendix A: Correlation Matrix}

The table presents the correlation matrix between the independent variables used in the analysis

\begin{tabular}{|c|c|c|c|c|c|c|c|c|c|c|c|c|c|c|c|c|c|}
\hline & & 1 & 2 & 3 & 4 & 5 & 6 & 7 & 8 & 9 & 10 & 11 & 12 & 13 & 14 & 15 & 16 \\
\hline 1 & Log (Vega) & 1.00 & & & & & & & & & & & & & & & \\
\hline 2 & $\log ($ Delta $)$ & 0.53 & 1.00 & & & & & & & & & & & & & & \\
\hline 3 & $\log ($ Age $)$ & 0.24 & 0.21 & 1.00 & & & & & & & & & & & & & \\
\hline 4 & Log(Assets) & 0.64 & 0.62 & 0.31 & 1.00 & & & & & & & & & & & & \\
\hline 5 & Log(Proved Reserves) & 0.67 & 0.49 & 0.29 & 0.87 & 1.00 & & & & & & & & & & & \\
\hline 6 & ROA & -0.03 & 0.12 & 0.18 & -0.02 & 0.08 & 1.00 & & & & & & & & & & \\
\hline 7 & Ln(Cash Comp.) & 0.54 & 0.59 & 0.27 & 0.78 & 0.70 & 0.04 & 1.00 & & & & & & & & & \\
\hline 8 & Leverage & -0.06 & -0.25 & -0.33 & -0.14 & -0.10 & -0.34 & -0.16 & 1.00 & & & & & & & & \\
\hline 9 & Dividend & 0.54 & 0.36 & 0.27 & 0.49 & 0.47 & 0.09 & 0.39 & -0.05 & 1.00 & & & & & & & \\
\hline 10 & Tobin Q & -0.17 & 0.16 & 0.01 & -0.20 & -0.10 & 0.46 & -0.12 & -0.32 & 0.01 & 1.00 & & & & & & \\
\hline 11 & Cash Reserves & -0.15 & -0.08 & 0.07 & -0.20 & -0.11 & 0.09 & -0.06 & -0.36 & -0.10 & 0.23 & 1.00 & & & & & \\
\hline 12 & Duality & 0.35 & 0.34 & 0.30 & 0.39 & 0.34 & 0.02 & 0.44 & 0.00 & 0.30 & -0.08 & -0.09 & 1.00 & & & & \\
\hline 13 & Overconfidence & -0.21 & 0.21 & -0.02 & -0.09 & -0.16 & 0.18 & -0.04 & -0.23 & -0.10 & 0.27 & 0.05 & -0.04 & 1.00 & & & \\
\hline 14 & $\log ($ Capex/PPE) & -0.37 & -0.14 & -0.14 & -0.38 & -0.52 & 0.11 & -0.34 & -0.12 & -0.28 & 0.18 & 0.02 & -0.26 & 0.1 & 1.0 & & \\
\hline 15 & Tenure & 0.16 & 0.46 & 0.24 & 0.17 & 0.12 & 0.14 & 0.26 & -0.05 & 0.23 & 0.11 & 0.02 & 0.20 & 0.1 & 0.1 & 1.00 & \\
\hline 16 & Fin. Expertise & -0.05 & -0.04 & -0.12 & -0.10 & -0.06 & 0.06 & -0.06 & 0.10 & 0.08 & 0.01 & -0.06 & -0.03 & 0.1 & 0.0 & -0.09 & 1.00 \\
\hline
\end{tabular}




\section{Figure 1 - Hedging instrument choice over time}

The figure shows how hedging instrument choice evolved over time for our sample of US oil and gas firms between 2000 and 2008. All hedging strategies are expressed as a fraction of the total hedging observations in that year. The categories are mutually exclusive and each firm-year is classified to belong to a particular strategy if that strategy is the dominant (i.e. largest) in the firm's portfolio of derivatives in that year.

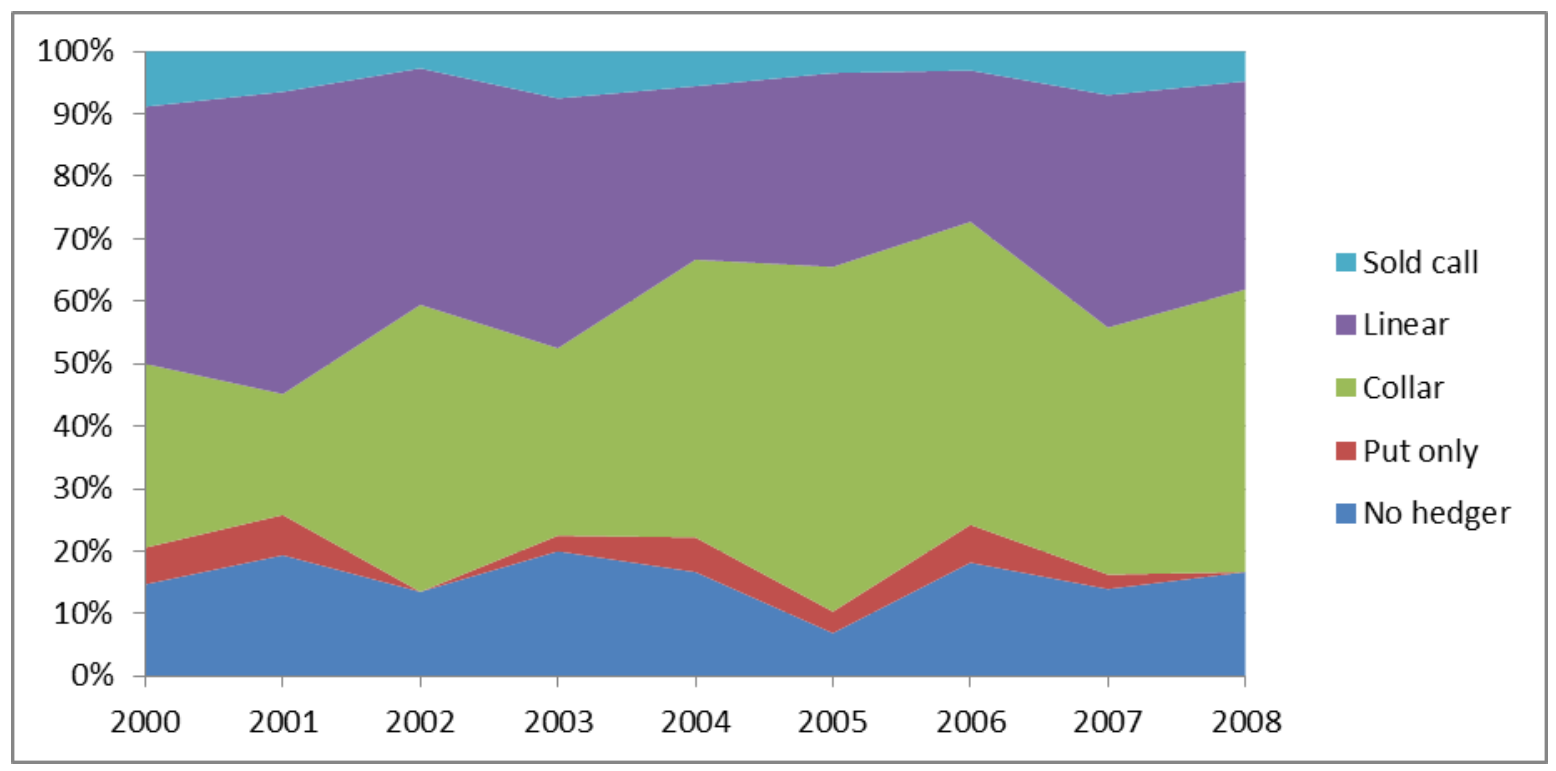




\section{Appendix A: Variable Definitions}

\begin{tabular}{|c|c|}
\hline \multicolumn{2}{|l|}{ Hedging Variables } \\
\hline Hedger & Binary variable that takes the value 1 if the firm is a user of financial derivatives \\
\hline Linear & $\begin{array}{l}\text { Binary variable that takes the value } 1 \text { if the firm is a user of linear hedging } \\
\text { instruments (i.e. forward or future contracts, price swap agreements, etc) }\end{array}$ \\
\hline Lost Upside & $\begin{array}{l}\text { Binary variable that takes the value } 1 \text { if the firm uses a hedging strategy that } \\
\text { involves capping the upside potential, i.e. entering linear contracts or selling call } \\
\text { options }\end{array}$ \\
\hline Sold Put & $\begin{array}{l}\text { Binary variable that takes the value } 1 \text { if the firm uses a hedging strategy that } \\
\text { involves the purchasing of put options }\end{array}$ \\
\hline Bought Call & $\begin{array}{l}\text { Binary variable that takes the value } 1 \text { if the firm uses a hedging strategy that } \\
\text { involves the buying of call options }\end{array}$ \\
\hline Extent of Insurance & Puts/(linear contracts+put) \\
\hline Extent of Selling Calls & Calls/(linear contracts+min(calls;puts)) \\
\hline Extent of Collar & Min(calls;puts)/(linear contracts+calls) \\
\hline Extent of Linear & Linear contracts/(linear contracts+max(calls;puts) \\
\hline \multicolumn{2}{|l|}{ CEO Variables } \\
\hline Cash Compensation & (ExecuComp data item TCC). It includes salary and bonus in the fiscal year. \\
\hline CEO Age & It is the age of the CEO from ExecuComp. \\
\hline CPI at Birth & $\begin{array}{l}\text { Consumer price index in the year when the CEO was born. Data are from the } \\
\text { Bureau of Labor Statistics, US Department of Labor. }\end{array}$ \\
\hline Tenure & Number of years since the CEO took office \\
\hline Delta & $\begin{array}{l}\text { The change in the dollar value of the CEO wealth for a one percentage point } \\
\text { change in stock price at the end of the fiscal year. }\end{array}$ \\
\hline Duality & $\begin{array}{l}\text { Binary variable that takes the value of } 1 \text { if the roles of CEO and Chairman of the } \\
\text { board are not split, } 0 \text { otherwise. The variable is created using data from } \\
\text { RiskMetrics }\end{array}$ \\
\hline Overconfidence & $\begin{array}{l}\text { Binary variable that takes the value of } 1 \text { when the CEO is identified as } \\
\text { overconfident, } 0 \text { otherwise. A CEO is overconfident if she postpones the } \\
\text { exercise of vested options that are at least } 67 \% \text { in the money. Overconfidence is } \\
\text { measured for every sample year. Firstly, for each CEO-year, the total realizable } \\
\text { value of the options is divided by the number of options held by the CEO to } \\
\text { determine the average realizable value per option. The strike price is calculated } \\
\text { as the fiscal year-end stock price minus the average realizable value. The } \\
\text { average moneyness of the options is then calculated as the stock price divided by } \\
\text { the estimated strike price minus one. Only the vested options held by the CEO } \\
\text { are included in the computation. The variable is created using data from } \\
\text { ExecuComp. }\end{array}$ \\
\hline Vega & $\begin{array}{l}\text { Vega is the change in the dollar value of the CEO wealth for a one percentage } \\
\text { change in the annualized standard deviation of stock returns at the end of the } \\
\text { fiscal year. }\end{array}$ \\
\hline Financial Expertise & $\begin{array}{l}\text { CEO who has past experience in either banking or investment firms, in a } \\
\text { finance-related role (Accountant, CFO, Treasurer, or VP of Finance), or in an } \\
\text { auditing firm. }\end{array}$ \\
\hline Financial Eduation & $\begin{array}{l}\text { Binary variable that takes value } 1 \text { if the CEO has a MBA degree or any degree in } \\
\text { Economics, Finance, or Accouting. }\end{array}$ \\
\hline \multicolumn{2}{|l|}{ Firm Variables } \\
\hline Assets & The firm total assets at the fiscal year-end $(A T)$. \\
\hline Ln(Capex/PPE) & $\begin{array}{l}\text { The ratio between capital expenditures and net property plant and equipment at } \\
\text { the fiscal year-end (CAPX/PPENT). }\end{array}$ \\
\hline Cash reserves & Cash and cash equivalent $(\mathrm{CHE})$, scaled by total assets (AT) \\
\hline Dividend Dummy & $\begin{array}{l}\text { Binary variable that equals one if a firm paid cash dividends }(D V T) \text { during a } \\
\text { fiscal year and zero otherwise }\end{array}$ \\
\hline Leverage & Total debt, scaled by total assets: $(D L T T+D L C) / A T$ \\
\hline Proved Reserves & Total proved reserves of oil (OGTPROIL) \\
\hline Tobin Q & $\begin{array}{l}\text { The market value of equity }(P R C C \text { times } C S H O) \text { plus total assets }(A T) \text { minus the } \\
\text { book value of equity }(c e q+t x d b) \text {, divided by total assets }(A T) \text {. }\end{array}$ \\
\hline
\end{tabular}




\section{APPENDIX B: The oil price between 1st quarter 2000 and 4th quarter 2008}

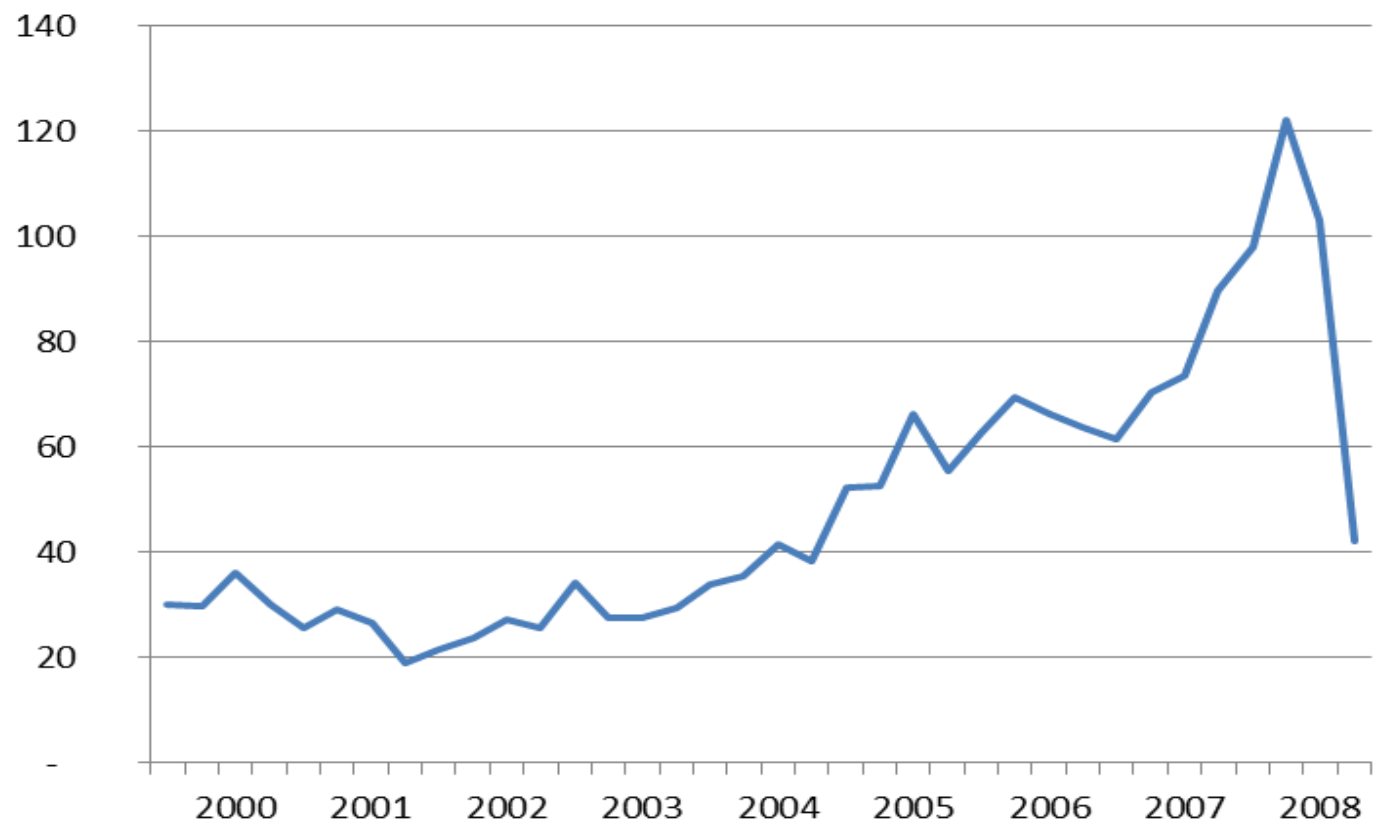

Fig.1. This graph shows the price of oil (West Texas Intermediate, nominal prices) between $1^{\text {st }}$ quarter 2008 and the $4^{\text {th }}$ quarter of 2008. In early 2004 the price of oil started a general rise that was to last until the final quarter of 2008 , when the price fell as a consequence of the financial crisis that erupted that year. However, even after the drop in the last quarter the oil price remained well above the long-term average prior to 2004. 